\title{
The Looming Collapse of Restrictions on Judicial Campaign Speech
}

\begin{abstract}
Nat Stern ${ }^{*}$
For the second time in four years, the American Bar Association (ABA) in 2007 overhauled its Model Code of Judicial Conduct. ${ }^{1}$ Like its provisional 2003 predecessor, ${ }^{2}$ the more recent edition focuses on compliance with the ruling of the United States Supreme Court in Republican Party of Minnesota $v$. White. ${ }^{3}$ In striking down a Minnesota provision barring a candidate for judicial office from "announc[ing] his or her views on disputed legal or political issues," the White Court concluded that the state's restriction improperly encroached on protected expression. ${ }^{5}$ On its face, the decision was confined to the defects of the "announce clause" under the First Amendment. The logic and tenor of the Court's opinion, however, called into question the broader enterprise of regulating speech by judicial candidates. Prior to White, states with elected judges had widely adopted campaign codes significantly limiting the speech and political activities of judicial candidates. The centerpiece of these codes consisted of prohibitions on statements ostensibly binding candidates on certain issues prior to confronting them in proper judicial proceedings. ${ }^{6}$ These and other restrictions were designed to shield the judiciary's independence and neutrality from erosion by the usual dynamics of political campaigns. The codes were thus defended as appropriately
\end{abstract}

\footnotetext{
* John W. and Ashley E. Frost Professor of Law, Florida State University College of Law. Research for this Article was supported by a grant from Florida State University. Joy-lynn Alvarez and Rachelle-Marie Gentner provided valuable research support.

Model Code of Judicial Conduct (2007), available at http://www.abanet.org/ judicialethics/ABA_MCJC_approved.pdf.

2 Model Code Of Judicial Conduct (1990) (amended 2003).

3536 U.S. 765 (2002).

${ }^{4}$ Id. at 768 (quoting Model Code of Judicial Conduct Canon 5(A) (3) (d) (i) (2002)).

$I d$. at 770-74 (finding that the "announce clause" failed strict scrutiny).

${ }^{6}$ See infra notes 34-43 and accompanying text.
} 
balancing judicial impartiality with the competing interests of democratic accountability and free speech. ${ }^{7}$

Like the ABA, many states revised their judicial conduct codes after White while trying to salvage the essence of their earlier regulatory regimes. ${ }^{8}$ This Article contends, however, that efforts to preserve potent constraints on judicial campaign speech are overwhelmingly doomed to failure. Whatever the merits of restrictions in the abstract, White has nullified their underlying premise: viz., that a state, having chosen to select judges through elections, can substantially modify the ordinary operation of principles governing political speech. Rather, White embodies rejection of the notion that states can insulate judicial campaign speech from these principles. It therefore appears likely that other provisions coming before the Court will receive the harsh scrutiny that almost invariably invalidates contentbased restrictions on the speech of political candidates. ${ }^{9}$ In light of that philosophy, it is reasonable to expect that most attempts to curtail judicial candidates' speech will suffer the same fate as Minnesota's announce clause.

While a pessimistic forecast for judicial campaign restrictions is not novel, ${ }^{10}$ this Article examines their dim prospects from a variety of perspectives. Part I provides a brief overview of judicial elections and the evolution of campaign speech codes, the Court's reasoning in White, and the decision's aftermath. Part II characterizes White as one of a series of major decisions whose full implications have unfolded in phases. To support the thesis that White's reach will far transcend the announce clause, this Part first argues that an expansive construction offers a more coherent explanation of the Court's opinion than assuming leniency toward other restrictions. The pattern of lower court rulings confirms and reinforces this understanding of White. In addition, realistically considered, a hostile stance toward curbing judicial campaign expression appears more consistent with the ideological preferences of the Court's majority. Finally,

\footnotetext{
${ }^{7}$ See, e.g., Jason Miles Levien \& Stacie L. Fatka, Cleaning up Judicial Elections: Examining the First Amendment Limitations on Judicial Campaign Regulation, 2 MicH. L. \& POL'y Rev. 71, 84-88 (1997); Randall T. Shepard, Campaign Speech: Restraint and Liberty in Judicial Ethics, 9 GEO. J. LEGAL ETHICS 1059, 1060 (1996).

8 See infra notes 34-43 and accompanying text.

9 See Erwin Chemerinsky, Restrictions on the Speech of Judicial Candidates are Unconstitutional, 35 IND. L. REv. 735 (2002) [hereinafter Chemerinsky, Restrictions] (urging this approach toward the Model Code shortly before the decision in White was issued).

See infra note 97.
} 
White resembles decisions in other areas in which an ultimately expansive doctrine was somewhat obscured by the specific setting in which it arose. Assuming this strict approach, Part III describes how specific restrictions on candidates' speech and related activity can be invalidated. Part IV briefly surveys the likely landscape of an elected judiciary unhampered by enforceable campaign restrictions, and notes alternatives available to critics of politicized judicial races. ${ }^{11}$

\section{JUdiCIAL ELECTIONS, CAMPAIGN SPEECH LIMITATIONS, AND THE REACTION TO WHITE}

The widespread selection of state judges through popular election forms the critical backdrop to White. That practice in turn has evoked special restrictions on judicial electioneering rooted in courts' distinctive role under the separation of powers. White sent an emphatic though imprecise signal of the Court's impatience with this justification for limiting judicial campaign speech. Scholars, states, courts, and bar associations have since sought to discern the ultimate contours of the power to regulate this expression.

\section{A. An Elected Judiciary, its Critics, and the Progress of} Campaign Speech Codes

Although various appointive systems of selecting state judges marked the nation's early history, ${ }^{12}$ the mid-nineteenth century witnessed a widespread shift to judicial elections. ${ }^{13}$ The movement toward popular election is widely attributed to the Jacksonian democ-

11 The Article does not add to the abundant literature analyzing the relative merits of electing and appointing judges. See infra notes 17-26 and accompanying text (offering a sampling of such criticism). Likewise, while judicial candidates' solicitation of campaign contributions is discussed in Part III.E, infra, debate over the regulation of judicial campaign finance lies beyond the scope of the Article. For contributions to that debate, see, e.g., Kathryn Abrams, Some Realism About Electoralism: Rethinking Judicial Campaign Finance, 72 S. CAL. L. Rev. 505 (1999); David Barnhizer, "On the Make": Campaign Funding and the Corrupting of the American Judiciary, 50 CATH. U. L. Rev. 361 (2001); Erwin Chemerinsky, Preserving an Independent Judiciary: The Need for Contribution and Expenditure Limits in Judicial Elections, 74 CHI.-KeNT L. REV. 133 (1998); Yoav Dotan, Campaign Finance Reform and the Social Inequality Paradox, 37 U. MiCH.J.L. REFORM 955 (2004).

${ }^{12}$ Glenn R. Winters, Selection of Judges-An Historical Introduction, 44 TEX. L. REv. 1081, 1081-82 (1966).

13 See Evan Haynes, The Selection And Tenure OF Judges 80-135 (1944); Kermit L. Hall, The Judiciary on Trial: State Constitutional Reform and the Rise of an Elected Judiciary, 1846-1860, 45 HISTORIAN 337 (1983). 
ratic impulse of that period. ${ }^{14}$ Since then, the idea of judicial accountability to voters has had enduring appeal; judicial elections are now held in a variety of forms in thirty-nine states. ${ }^{15}$ By one oft-cited calculation, approximately eighty-seven percent of state judges stand for popular election at least once in their career. ${ }^{16}$

Despite their popularity, elections have long been opposed as a means of choosing judges. Alexander Hamilton famously urged the lifetime appointment of judges to ensure their independence from both other branches and the popular will. ${ }^{17}$ While the Constitution implemented Hamilton's proposal for the federal judiciary, ${ }^{18}$ state elections have left modern critics amplifying his concerns. Many regard judicial elections as incompatible with the independence and impartiality that judging requires. ${ }^{19}$ Observers have asserted an inevitable collision between a judge's obligation to follow the law and a

14 See, e.g., James W. Hurst, The Growth of American LaW: The LaW Makers 140 (1950); Joseph R. Grodin, Developing a Consensus of Constraint: A Judge's Perspective on Judicial Retention Elections, 61 S. CAL. L. REV. 1969, 1970-71 (1988); see also FrANCIS R. Aumann, The Changing American Legal Systems 187-89 (1940) (suggesting that Jacksonian Democrats also sought to replace Whig judges with party loyalists).

${ }^{15}$ See Am. Judicature Society, Judicial Selection of the States: Appellate ANd GENERAL JURISDICTION COURTS (2004), http://www.ajs.org/js/JudicialSelectionCharts .pdf. This website, periodically updated, reports methods of judicial selection among the states under a number of categories. The distinctions noted include those between initial selection and retention; between partisan and nonpartisan elections; and among trial courts, intermediate appellate courts, and courts of last resort. Id.; see also The Council of State Governments, The Book of the States 251-54 (2006) (charting selection and retention of state governments). For a chart summarizing selection and retention systems for state court judges, see Roy A. Schotland, Should Judges Be More Like Politicians?, CT. REV., Spring 2002, at 8, 10 [hereinafter Schotland, Should Judges].

${ }^{16}$ Robert C. Berness, Note, Norms of Judicial Behavior: Understanding Restrictions on Judicial Candidate Speech in the Age of Attack Politics, 53 Rutgers L. REV. 1027, 1028 (2001).

17 The Federalist No. 78 (Alexander Hamilton).

18 See U.S. CONST. art. II, § 2, cl. 2 (providing for appointment by president with advice and consent of the Senate); $i d$. art. III, $\S 1$ (providing that judges shall hold office "during good Behaviour").

19 See, e.g., Mark A. Behrens \& Cary Silverman, The Case for Adopting Appointive Judicial Selection Systems for State Court Judges, 11 Connell J.L. \& Pub. Pol’y 273, 277-78 (2002); Matthew J. O'Hara, Restriction of Judicial Election Candidates' Free Speech Rights After Buckley: A Compelling Constitutional Limitation?, 70 CHI.-KenT L. REv. 197, 235 (1994) (asserting that only lifetime appointment "can fully insulate judges from the pressure to conform their decisions to the beliefs of others"); Penny J. White, Preserving the Legacy: A Tribute to Chief Justice Harry L. Carrico, One who Exalted Judicial Independence, 38 U. Rich. L. REV. 615, 616 (2004). 
candidate's need to court popularity. ${ }^{20}$ In some instances, it is suggested, judges succumb to the temptation to act politically rather than judicially. ${ }^{21}$ In particular, the threat of undue responsiveness to popular sentiment is framed as the "majoritarian difficulty" that arises when elected judges are called upon to protect unpopular liberties. ${ }^{22}$ In one view, resolution of cases by judges who must answer to the electorate inherently threatens-or even violates-due process. ${ }^{23}$ Even if judges can disregard the potential electoral consequences of their decisions, "the public's confidence in the judiciary could be undermined simply by the possibility that judges would be unable to do so." ${ }^{24}$ Moreover, voters are said to be insufficiently informed to make thoughtful choices among judicial candidates. ${ }^{25}$ Finally, the recent

20 See, e.g., Steven P. Croley, The Majoritarian Difficulty: Elective Judiciaries and the Rule of Law, 62 U. CHI. L. REv. 689, 726-29 (1995); Charles Gardner Geyh, Why Judicial Elections Stink, 64 OHIo ST. L.J. 43, 51 (2003). But see Michael R. Dimino, Sr., The Worst Way of Selecting Judges-Except all the Others that Have Been Tried, 32 N. Ky. L. Rev. 267, 267-73 (2005) (questioning whether electoral accountability renders state judges incapable of protecting rights guaranteed in state constitutions).

See, e.g., Am. Bar Ass'n, Section of Judicial Admin., The Improvement of the AdMINISTRATION OF JUSTICE 45 (5th ed. 1971) (stating that " $[\mathrm{t}]$ he curse of the elective system is that it turns every judge into a politician"); Gregory A. Huber \& Sanford C. Gordon, Accountability and Coercion: Is Justice Blind When It Runs For Office?, 48 AM. J. POL. SCI. 247, 258 (2004) (finding that judges increase sentences awarded as reelection approaches); Gerald F. Uelmen, Crocodiles in the Bathtub: Maintaining the Independence of State Supreme Courts in an Era of Judicial Politicization, 72 NOTRE DAME L. REV. 1133, 1133 (1997) (comparing situation of judge deciding controversial cases while facing reelection to "finding a crocodile in your bathtub" in that "it's hard to think about much else while you're shaving"); see also Marie A. Failinger, Can a Good Judge Be a Good Politician? Judicial Elections from a Virtue Ethics Approach, 70 Mo. L. Rev. 433, 465-513 (2005) (arguing against judicial elections on grounds that qualities that make someone a good judge are generally different from those that make a person a good politician); Katie A. Whitehead, Comment, Loose Lips Sink Ships: The Implications of a Liberal Policy Restricting Judicial Speech, 28 S. ILL. U. L.J. 159, 170 (2003).

${ }_{22}$ See, e.g., Croley, supra note 20, at 694, 787-90; Robert A. Schapiro, Polyphonic Federalism: State Constitutions in the Federal Courts, 87 CAL. L. REv. 1409, 1415, 1438 (1999).

23 See Robert M. O'Neil, The Canons in the Courts: Recent First Amendment Rulings, 35 InD. L. Rev. 701, 723 (2002); Scott D. Weiner, Note, Popular Justice: State Judicial Elections and Procedural Due Process, 31 HARV. C.R.-C.L. L. REV. 187, 188-89 (1996).

${ }^{24}$ Republican Party of Minn. v. White, 120 U.S. 765, 789 (2002) (O'Connor, J., concurring).

${ }^{25}$ See Allen T. Klots, The Selection of Judges and the Short Ballot, in JUDICIAL SElection AND Tenure: Selected REAdings 83-84 (Glenn R. Winters ed., 1973); Marie Hojnacki \& Lawrence Baum, Choosing Judicial Candidates: How Voters Explain Their Decisions, 75 Judicature 300, 300-02 (1992); NATIONAL Center FOR STATE Courts, CAll to Action: Statement of the National Summit on ImProving Judicial SELECTION 40-42 (expanded ed. 2002), http://www.ncsconline.org/WC/p ublications/Res_JudSel_CallToActionPub.pdf [hereinafter CALL TO ACTION]. 
sharp rise in judicial campaign spending has aroused suspicion that judicial decisions can be colored by a sense of obligation to contributors. ${ }^{26}$

Dissatisfaction with the putative flaws of judicial elections has sparked repeated calls for replacing them with "merit selection" through appointment. Under this method, the governor selects a judge from a list compiled by a nonpartisan judicial nominating commission. ${ }^{27}$ The ABA has conspicuously endorsed merit selection for decades. ${ }^{28}$ As currently championed by the American Judicature Society, the system includes a concession to the desire for democratic accountability: viz., exposing judges to an uncontested retention election after a specified term. ${ }^{29}$ Also known as the Missouri Plan, this approach was apparently endorsed by Justice O'Connor in her concurrence in White. ${ }^{30}$ While sixteen states employ the Missouri plan or another appointment system, ${ }^{31}$ the broader effort to supplant judicial elections with appointments has foundered on public resistance. A poll conducted in 2001 found that voters in states with elected judges overwhelmingly preferred election to appointment; ${ }^{32}$ the resounding defeats of proposals in Ohio and Florida to switch from elective to appointive systems ${ }^{33}$ appear to confirm this attitude.

Faced with the reality that "people want to elect judges," ${ }^{34}$ states have tried to deter campaign abuses through limitations on the speech of judicial candidates. Such restrictions, part of a general

${ }^{26}$ See David Goldberger, The Power of Special Interest Groups to Overwhelm Judicial Election Campaigns: The Troublesome Interaction Between the Code of Judicial Conduct, Campaign Finance Laws, and the First Amendment, 72 U. CIN. L. REv. 1 (2003); Adam Liptak \& Janet Roberts, Campaign Cash Mirrors a High Court's Rulings, N.Y. Times, Oct. 1, 2006, at A1; Press Release, American Bar Association, Poll: Confidence in Judiciary Eroded by Judges' Need to Raise Campaign Money (Aug. 12, 2002).

${ }^{27}$ Behrens \& Silverman, supra note 19, at 301.

${ }^{28} I d$.

29 Am. Judicature Society, Merit Selection: The Best Way to Choose the Best JuDGES, http://www.ajs.org/js/ms_descrip.pdf (last visited Dec. 31, 2007).

${ }^{30}$ See Republican Party of Minn. v. White, 536 U.S. 765, 791-92 (2002) (O’Connor, J., concurring).

31 Anca Cornis-Pop, Republican Party of Minnesota v. White and the Announce Clause in Light of Theories of Judge and Voter Decisionmaking: With Strategic Judges and Rational Voters, the Supreme Court was Right to Strike Down the Clause, 40 WillameTte L. REV. 123, 130 \& n.45 (2004) (collecting states' provisions for appointment).

${ }^{32}$ Thomas R. Phillips, Electoral Accountability and Judicial Independence, 64 OHIO ST. L.J. 137, 145 n.55 (2003).

33 See Roy A. Schotland, Financing Judicial Elections, 2000: Change and Challenge, 2001 Mich. ST. L. REv. 849, 886-90 (2001) [hereinafter Schotland, Financing].

${ }^{34}$ Jan Witold Baran, Judicial Candidate Speech After Republican Party of Minnesota v. White, CT. REv., Spring 2002, at 12. 
code of judicial ethics, originated in the ABA's 1924 Canons of Judicial Ethics. ${ }^{35}$ Hortatory and vague,${ }^{36}$ this early version did not impose enforceable restraints on campaign expression. ${ }^{37}$ When the ABA replaced the 1924 canons with the Model Code of Judicial Conduct ${ }^{38}$ in 1972, however, the new canon on campaign activity contained considerably stronger language. Its key provision stated that "[a] candidate for judicial office should not make pledges or promises of conduct in office other than the faithful and impartial performance of the duties of the office; announce his views on disputed legal or political issues; or misrepresent his identity, qualifications, present position, or other fact." ${ }^{39}$ Later, concern about potential overbreadth ${ }^{40}$ prompted the ABA to eliminate the announce clause. The 1990 revised Model Code ${ }^{41}$ instead prohibited candidates from making "statements that commit or appear to commit the candidate with respect to cases, controversies or issues that are likely to come before the court." ${ }^{42}$ On the eve of the Court's decision in White, most states with elected judges had adopted "campaign speech restrictions patterned after" the 1972 or 1990 model canons. ${ }^{43}$

These rules were driven by a belief that traditional campaign platforms conflict with the ideal of judicial neutrality. To attract support, a judicial candidate may make a commitment to decide a certain kind of case in a particular way. ${ }^{44}$ If elected, the successful candidate would presumably feel obligated to act in accordance with that commitment. ${ }^{45}$ Since judicial decisionmaking contemplates the unbiased consideration of evidence and arguments, such commitments represent "the antithesis of the judicial process." ${ }^{46}$ Moreover, even

35 CAnOns of Judicial Ethics 30 (1924) (amended 1933).

${ }^{36}$ See id. (providing, inter alia, that a candidate "should do nothing . . . to create the impression that if chosen, he will administer his office with bias, partiality or improper discrimination").

See Max Minzner, Gagged but not Bound: The Ineffectiveness of the Rules Governing Judicial Campaign Speech, 68 UMKC L. Rev. 209, 212-13 (1999).

38 Model Code of Judicial Conduct (1972).

39 Id. Canon $7(\mathrm{~B})(1)(\mathrm{c})$.

40 See Model Code of Judicial Conduct app. C (1990).

41 Model Code of Judicial Conduct (1990) (amended 2003).

${ }^{42} I d$. Canon 5(A) (3) (d) (ii). 2001)

Republican Party of Minn. v. Kelly, 247 F.3d 854, 880, 880 nn.21-22 (8th Cir.

${ }^{44}$ See Buckley v. Ill. Judicial Inquiry Bd., 997 F.2d 224, 228 (7th Cir. 1993).

45 See id.; Melinda Gann Hall, Justices as Representatives: Elections and Judicial Politics in the American States, 23 AM. PoL'Y Q. 485, 495-97 (1995).

${ }^{46}$ Stephen Gillers, "If Elected, I Promise [ ]"-What Should Judicial Candidates Be Allowed to Say?, 35 IND. L. Rev. 725, 726 (2002); see also Megan Sloane Gordon \& Mat- 
where judges remain unaffected by campaign assurances, the appearance of justice is said to suffer when judicial rulings coincide with candidate commitments. Nor will it be only losing parties who question whether they received "a fair hearing by an independent and impartial judge." ${ }^{47}$ Campaign stances on issues, it is argued, also undermine public confidence in the judiciary by fostering the perception of candidates as political aspirants rather than "impartial arbiters who follow the dictates of the law." ${ }^{48}$ Restrictions on candidates' campaign rhetoric have thus been explained as serving " $[\mathrm{t}]$ he state's interest in ensuring that judges be and appear to be neither antagonistic nor beholden to any interest, party, or person." ${ }^{49}$

Notably, a strong sense of the judiciary's fundamentally distinct character informs these justifications for limiting campaign speech. Defenders of restrictions believe that a "critical difference" ${ }^{50}$ exists between the function of the judge and that of others in government. They contrast the representative capacity of legislators and executives with the obligation of judges to serve no constituency. ${ }^{51}$ While voters expect legislative and executive officials to abide by promises to enact certain policies, judges cannot be bound to specific outcomes in advance of trial or arguments. ${ }^{52}$ Those who attain legislative and execu-

thew Edward Wetzel, The Precarious Balance of Judicial Candidate Speech and Judicial Ethics: The Announce Clause in the Aftermath of Republican Party of Minnesota v. White, 16 GeO. J. LeGAL ETHICS 613, 618 (2003) (stating that campaign promises "are completely antithetical to the ideas of neutrality, unbiasedness, and cold impartiality that inhere to the judiciary").

47 Gerald Stern, The Changing Face of Judicial Elections, 32 HoFstRA L. REv. 1507, 1509 (2004) (asserting that "parties on the 'wrong' side of the issues" on which judges have committed themselves "cannot be confident that they will receive fair hearings").

${ }^{48}$ Lloyd B. Snyder, The Constitutionality and Consequences of Restrictions on Campaign Speech by Candidates for Judicial Office, 35 UCLA L. REV. 207, 214 (1987) (noting this justification for restrictions on campaign speech); see Stretton v. Disciplinary Bd. of Sup. Ct. of Pa., 944 F.2d 137, 142 (3d Cir. 1991) (stating as justification for announce clause that "[i]f judicial candidates during a campaign prejudge cases that later come before them, the concept of impartial justice becomes a mockery"); Shepard, supra note 7, at 1067 (defending restrictions as helping judges to avoid "hurly-burly of sometimes political strife" and to "ensure that courts are perceived as even-handed institutions").

${ }^{49}$ Morial v. Judiciary Comm'n, 565 F.2d 295, 302 (5th Cir. 1977).

${ }^{50}$ Republican Party of Minn. v. White, 536 U.S. 765, 798 (2002) (Stevens, J., dissenting).

51 See, e.g., id. at 805 (Ginsburg, J., dissenting); SARAh Mathias, Electing Justice: A HANDBOOK OF JUdicial EleCtion ReFORMS 5 (1990).

${ }^{52}$ See Ackerson v. Ky. Judicial Ret. \& Removal Comm'n, 776 F. Supp. 309, 313 (W.D. Ky. 1991); Ofer Raban, Judicial Impartiality and the Regulation of Judicial Election Campaigns, 15 U. FLA. J.L. \& PUB. POL'Y 205, 214 (2004) (“[O]pinions which election- 
tive office rely on broad popular appeal; a crucial duty of the judge is to sustain minority rights in the teeth of popular hostility. ${ }^{53}$ In short, the very essence of a judge is not to be a politician, and campaign speech restrictions are seen as an important mechanism for preventing this confusion of roles. ${ }^{54}$

Even before White, however, many judicial candidates disputed the sufficiency of this rationale. The 1990s alone produced over a dozen rulings on challenges to campaign speech restrictions. Early in the decade, results were roughly balanced between acceptance and rejection of arguments that these limitations trenched on protected speech. ${ }^{55}$ Decisions from the same part of the following decade, however, reflected increasing judicial animosity toward restrictions. ${ }^{56}$ An exception was the Eighth Circuit's decision in Republican Party of Minnesota v. Kelly, ${ }^{57}$ sustaining Minnesota's announce clause as narrowly construed. ${ }^{58}$ It was this holding that the Supreme Court overturned in White.

eering legislators are free to express and then to try to act upon may be totally out of bounds for elected judges and a threat to their duties of office.").

${ }_{53}$ See United States v. Carolene Prods., 304 U.S. 144, 152 n.4 (1938); Stern, supra note 47, at 1511 (stating that "basic, well-established rights are not subject to what a majority of voters want, and a judge's loyalty must be to the law and ... not to the wishes of voters").

${ }^{54}$ Alan B. Morrison, The Judge Has No Robes: Keeping the Electorate in the Dark About What Judges Think About the Issues, 36 IND. L. REv. 719, 731 (2003) (citing proposition that judges "are not politicians, and they should not act like them" as supporting ban on pledges by judicial candidates).

Compare, e.g., ACLU of Fla. v. Fla. Bar, 744 F. Supp. 1094, 1096-98 (N.D. Fla. 1990) (invalidating state's announce clause), and J.C.J.D. v. R.J.C.R., 803 S.W.2d 953, 954-55 (Ky. 1991), cert. denied, 502 U.S. 816 (1991) (invalidating state's announce clause), with, e.g., Stretton v. Disciplinary Bd. of Sup. Ct. of Pa., 944 F.2d 137, 140-43 (3d Cir. 1991) (upholding state's announce clause on interpretation that clause applied only to issues likely to come before the court), and Ackerson, 776 F. Supp. at 314-15 (sustaining state's commit clause except as applied to comments on issues regarding court administration).

See Weaver v. Bonner, 114 F. Supp. 2d 1337, 1342-43 (N.D. Ga. 2000) (striking down ban on false statements by judicial candidates), aff'd in part, rev'd in part, 309 F.3d 1312 (11th Cir. 2002); Butler v. Ala. Judicial Inquiry Comm., 802 So. 2d 207 (Ala. 2001) (overturning ban on statements "that would be deceiving or misleading to a reasonable person"); In re Chmura, 608 N.W.2d 31, 41 (Mich. 2000), cert. denied, 531 U.S. 828 (2000) (invalidating ban on false statements).

${ }^{57} 247$ F.3d 854, 857 (8th Cir. 2001), aff'g 63 F. Supp. 2d 967 (D. Minn. 1999), rev'd sub nom. Republican Party of Minn. v. White, 536 U.S. 765 (2002).

${ }^{58} I d$. at 881-82 (interpreting prohibition as applying only to issues likely to come before the court). 


\section{B. The White Decision and its Repercussions}

As noted earlier, the announce clause struck down in White prohibited a candidate for judicial office from "announc[ing] his or her views on disputed legal or political issues." ${ }^{\text {"9 }}$ The challenge was originally brought by a former candidate for the Minnesota Supreme Court; he was later joined by the Minnesota Republican Party and others. ${ }^{60}$ In reviewing the clause, the Court proceeded on the Eighth Circuit's premise-accepted by the parties-that this type of restriction warranted strict scrutiny. ${ }^{61}$ Minnesota was therefore obliged to demonstrate that the announce clause was narrowly tailored to serve its asserted compelling state interest in judicial impartiality and the appearance of impartiality. ${ }^{62}$ Although the court of appeals had reached just this conclusion, ${ }^{63}$ the Court found that the Eighth Circuit's references to "impartiality" suffered from lack of definitional clarity. ${ }^{64}$ Accordingly, Justice Scalia's opinion revolved around the interpretation of that term in the context of judicial behavior.

First, the Court considered the "traditional" meaning of judicial impartiality as the "lack of bias for or against either party to the proceeding." ${ }^{65}$ While recognizing that due process requires this kind of impartiality, the Court found that the announce clause was not narrowly tailored to promote it. ${ }^{66}$ The Court distinguished between a restriction on speech "for or against particular parties" and the clause's more expansive prohibition of speech "for or against particular issues." ${ }^{" 67}$ Second, the Court entertained but rejected the notion of impartiality as "lack of preconception in favor of or against a particular legal view." ${ }^{68}$ Even if the announce clause advanced this interest, the Court deemed this quality "neither possible nor desirable" in a judge $;{ }^{69}$ anyone qualified to serve as a judge will have formed views on

${ }^{59}$ White, 536 U.S. at 768 (quoting MinN. CodE OF Judicial Conduct Canon $5(\mathrm{~A})(3)(\mathrm{d})(\mathrm{i})(2000))$.

${ }^{60}$ See Brief for Petitioners, Republican Party of Minn. v. White, 536 U.S. 765 (2002) (No. 01-521).

${ }^{61}$ White, 536 U.S. at 774.

${ }^{62} I d$. at 774-75.

63 Kelly, 247 F.3d at 867.

${ }^{64}$ White, 536 U.S. at 775.

${ }^{65} I d$. at 775 .

${ }^{66} I d$. at 776 .

${ }^{67} I d$.

${ }^{68}$ Id at 777.

${ }^{69} \quad I d$. at 778 . 
at least some legal issues. ${ }^{70}$ Finally, the Court addressed impartiality as meaning "openmindedness," or the willingness to consider views opposed to the judge's preconceptions. ${ }^{71}$ The Court declined to assess the strength of this interest because it did not believe that the Minnesota Supreme Court had adopted the announce clause for this purpose. Rather, the Court concluded, the clause was "so woefully underinclusive as to render belief in that purpose a challenge to the credulous." ${ }^{72}$ Since the ban was confined to the election campaign, it omitted a vast range of opportunities for the announcement of views that might compromise openmindedness or its appearance. ${ }^{73}$

While joining the Court's opinion, Justices O'Connor and Kennedy wrote separately to sound additional themes. Concurring to express "concerns about judicial elections generally," J4 Justice O'Connor emphasized the threat to impartiality posed by judicial sensitivity to electoral consequences and contributors' interests. ${ }^{75}$ Nevertheless, she concluded, a state that assumes these risks by continuing to hold judicial elections could not combat them through excessive restrictions on speech. ${ }^{76}$ Justice Kennedy, on the other hand, concurred to articulate a more far-reaching rationale than the Court's for invalidating the announce clause. The relevant principle, he argued, was that "content-based speech restrictions that do not fall within any traditional exception should be invalidated without inquiry." ${ }^{\text {,7 }}$ Accordingly, Minnesota's restraint on political speech was per se unconstitutional. ${ }^{78}$

Writing for the four dissenters, ${ }^{79}$ Justice Stevens attacked what he viewed as the two major fallacies of Court's opinion: an underappraisal of the "importance of judicial independence and impartiality, and an assumption that judicial candidates should have the same

\footnotetext{
${ }^{70}$ See White, 536 U.S. at 777-78; id. at 777 (stating that "it is virtually impossible to find a judge who does not have preconceptions about the law").

${ }^{71} I d$. at 778 .

72 Id. at 780 .

${ }^{73}$ See id. at 778-80; id. at 779 (observing that statements during campaigns amount to "an infinitesimal portion of the public commitments to legal positions that judges (or judges-to-be) undertake").

${ }^{74}$ Id. at 788 (O'Connor, J., concurring).

75 See id. at 788-90.

76 White, 536 U.S. at 792.

77 Id. at 793 (Kennedy, J., concurring).

78 See id. (calling direct restrictions on candidate speech "simply beyond the power of government").

${ }^{79}$ Justice Stevens was joined by Justices Souter, Ginsburg, and Breyer in dissent. See generally id.
} 
freedom" as campaigners for other offices "to express themselves on matters of current public importance." ${ }^{80}$ The "critical difference" between the functions of judges and of other public officials, Justice Stevens believed, defeated both of these assumptions. Also speaking for all the dissenters, Justice Ginsburg similarly emphasized that "judges perform a function fundamentally different" from that of elected representatives. ${ }^{82}$ Therefore, she argued, Minnesota was entitled to adopt an election process designed to safeguard the integrity of that function. ${ }^{83}$ In particular, she defended the announce clause as an indispensable adjunct to the state's protection of due process through its pledges or promises clause. ${ }^{84}$ Absent the announce clause, candidates could easily circumvent the ban on pledges and promises by couching them in the language of announcements. ${ }^{85}$

The split within the White Court was mirrored among commentators, whose reactions varied over the merit as well as the effect of the holding. Some echoed a lawyer for the plaintiffs ${ }^{86}$ in hailing the outcome as a signal victory for freedom of speech. ${ }^{87}$ Many others, however, denounced the decision in terms reminiscent of the dissenters in White. Numerous critics voiced their fear that the ruling could corrode judicial impartiality. ${ }^{88}$ In a similar vein, some accused

${ }^{80} 536$ U.S. at 797 (Stevens, J., dissenting) (citation omitted).

${ }^{81} I d$. at 798

82 Id. at 803 (Ginsburg, J., dissenting).

${ }^{83}$ See id. at 808-09.

${ }^{84} I d$. at 816 (noting potential for due process violations from judicial candidate's promise to rule certain way).

${ }^{85}$ Id. at 819

${ }^{86}$ See Terry Carter, Judicial Races, Litigation Likely to Heat Up, A.B.A. J. E-REPORT, Oct. 2005 (quoting lawyer as stating that the Court held that the First Amendment "applies with full force" to judicial elections).

See James L. Swanson, Judicial Elections and the First Amendment: Freeing Political Speech, 2002 Cato Sup. CT. Rev. 85, 86 (interpreting White as affirming that "we cannot have politics without robust and unfettered speech"); Morrison, supra note 54 , at 719 (asserting that benefits from public's learning candidates' views on issues "far outweigh the possible negative effects of permitting those views to be expressed during an election campaign"); Edward Walsh, Curbs on Judicial Hopefuls Lifted, WASH. Post, June 28, 2002, at A10 (quoting legal director of the ACLU as expressing the organization's concern that "the way to preserve judicial integrity is not to place restraints on candidates' speech"); Peter Gregory Juetten, Note, Should They Stay or Should They Go: The Implications of Republican Party of Minnesota v. White on Restrictions of Speech During Judicial Election Campaigns, 56 ARK. L. REv. 677, 695 (2003) (describing Minnesota's justification for announce clause as "implausible rationale for restricting speech").

${ }^{88}$ See, e.g., Failinger, supra note 21, at 486-88; Raban, supra note 52, at 212; David Neil McCarty, Note, Walk Before They Make Us Run: Republican Party of Minnesota v. White and the Need for Judicial Reform in Mississippi, 23 Miss. C. L. REV. 51, 65-66 
the Court of slighting due process rights. ${ }^{89}$ Also much like the dissents, a number of analyses faulted the Court for ignoring the distinctions between judges and "politicians." In addition, observers charged that the decision displayed an unrealistic grasp of election campaigns, ${ }^{91}$ encouraged interest groups' efforts to gain influence with judges, ${ }^{92}$ and would diminish the caliber of judicial candidates. ${ }^{93}$ A prominent scholar sympathetic to campaign speech regulation, however, had a more nuanced assessment. While conceding that the announce clause improperly intruded on protected speech, ${ }^{94}$ Richard Briffault discussed how White might be reconciled with the validity of other restrictions. ${ }^{95}$ Much other commentary as well has been marked by varying degrees of optimism that White left other significant restraints intact. ${ }^{96}$ At the same time, warnings of White's poten-

(2003); see also Brennan Ctr. for Justice, Republican Party of Minnesota v. White: What Does the Decision Mean for the Future of State Judicial Elections?, http://www. brennancenter.org/stack_detail.asp?key $=348 \&$ subkey $=35267$ (last visited Dec. 31, 2007) (asserting that White threatened loss of public faith in the elected judges' ability to decide issues "in a manner faithful to the adjudicative ideals of fairness and impartiality").

89 See, e.g., Angela Allen, Note, The Judicial Election Gag is Removed-Now Texas Should Remove its Gag and Respond, 10 TEX. WeSleyan L. REv. 201, 218-19 (2003); Rainbow Forbes, Note, Candidates' Speech in Judicial Elections According to Republican Party of Minnesota v. White: Is There a Better Way?, 30 N. Ky. L. Rev. 275, 291 (2003); Julie Schuering Schuetz, Comment, Judicial Campaign Speech Restrictions in Light of Republican Party of Minnesota v. White, 24 N. ILL. U. L. REv. 295, 338 (2004).

${ }^{90}$ See, e.g., Margaret H. Marshall, Dangerous Talk, Dangerous Silence: Free Speech, Judicial Independence, and the Rule of Law, 24 SYDNEY L. REV. 455, 467-68 (2002) (arguing that White "ignores an important distinction: Politicians break faith with the people when they abandon their advocacy. Judges break faith with the people when they abandon their neutrality."); White, supra note 19, at 624; see also David G. Savage, Running Stance: Judicial Candidates Now Free to Sound off on Election Issues, 88 A.B.A. J. 32, 32 (2002) (quoting ABA president as calling White "a bad decision [that] will open a Pandora's box" and lead to "judicial candidates running for office by announcing their positions on particular issues").

${ }^{91}$ See, e.g., David B. Bogard, Republican Party of Minnesota v. White: The Lifting of Judicial Speech Restraint, 26 U. ARK. LitTle Rock L. REV. 1, 14 (2003); Schotland, Should Judges, supra note 15 , at 8.

${ }_{92}$ See, e.g., Terry Carter, Boosting the Bench: The U.S. Chamber of Commerce is Spending Big Bucks to Influence Judicial Elections, 88 A.B.A J. 28, 34 (2002) [hereinafter Carter, Boosting]; Nathan Richard Wildermann, Comment, Bought Elections: Republican Party of Minnesota v. White, 11 GEO. MASOn L. REv. 765, 765 (2003).

${ }_{93}$ See, e.g., Schotland, Should Judges, supra note 15 , at 8.

${ }^{94}$ Richard Briffault, Judicial Campaign Codes After Republican Party of Minnesota v. White, 153 U. PA. L. REV. 181, 205-06 (2004).

${ }^{95}$ See id. at 209-33.

96 See, e.g., Francisco R. Maderal, Regulating Judicial Campaign Speech: Republican Party of Minnesota v. White on Remand, 19 GeO. J. Legal Ethics 809, 817-19 (2006); Katherine A. Moerke, Must More Speech be the Solution to Harmful Speech? Judicial Elec- 
tial for sweeping invalidation of restrictions have emanated in some quarters. $^{97}$

Revisions of state codes in the wake of White appeared to reflect a similar diversity of opinion about the decision's ultimate scope. Some responses were quite modest: e.g., Kentucky's proclamation that White did not affect its canon on judicial statements ${ }^{98}$ and Tennessee's replacing the state's commentary on its commit clause without formally amending the provision. ${ }^{99}$ In an obvious step, Pennsylvania hastened to retract its announce clause ${ }^{100}$ before the provision suffered its Texas counterpart's fate of post-White judicial disapproval. $^{101}$ White's impact on judicial conduct codes, however, reached

tions After Republican Party of Minnesota v. White, 48 S.D. L. REV. 262, 303-12 (2003); Bola Ogunro, How Can the Integrity of Judicial Elections be Safeguarded After White?, Commc'N LAWYER, Winter 2003, 19, 20; Barbara E. Reed, Tripping the Rift: Navigating Judicial Speech Fault Lines in the Post-White Landscape, 56 MERCER L. REV. 971, 982-85 (2005); Tobin A. Sparling, Keeping up Appearances: The Constitutionality of the Model Code of Judicial Conduct's Prohibition of Extrajudicial Speech Creating the Appearance of Bias, 19 GeO. J. Legal ETHICS 441, 444-45 (2006); Stern, supra note 47, at 1543; Wendy R. Weiser, Regulating Judges' Political Activity After White, 68 Alb. L. Rev. 651, 665-701 (2005); Catherine Ava Begaye, Note, Are There Any Limits on Judicial Candidates' Political Speech After Republican Party of Minnesota v. White?, 33 N.M. L. REv. 449, 472-74 (2003); Lindsay E. Lippman, Note, Republican Party of Minnesota v. White: The End of Judicial Election Reform?, 13 CORNELl J.L. \& PUB. POL'Y 137, 159-60 (2003); Wildermann, supra note 92, at 790-93; Alexandrea Haskell Young, Note, The First Chink in the Armor? The Constitutionality of State Laws Burdening Judicial Candidates After Republican Party of Minnesota v. White, 77 S. CAL. L. REv. 433, 461-66 (2004).

97 See, e.g., Michelle T. Friedland, Disqualification or Suppression: Due Process and the Response to Judicial Campaign Speech, 104 Colum. L. Rev. 563 (2004) (asserting that availability of disqualification of judges whose campaign speech displays bias leaves few or no restrictions on truthful campaign speech constitutional); Developments in the Law-Voting and Democracy, 119 HARV. L. REv. 1133, 1134 (2006) (stating that "the future looks bleak" for advocates of campaign speech restrictions); Joe Cutler, Note, Oops! I Said it Again: Judicial Codes of Conduct, the First Amendment, and the Definition of Impartiality, 17 GeO. J. Legal ETHICS 733, 743-44 (2004); Brian Morris, Free Speech in Judicial Elections, Mont. LAwyer, Aug. 2002, at 5; Richard L. Hasen, First Amendment Limits on Regulating Judicial Campaigns 2-3 (Loyola-LA Legal Studies Paper No. 20075), available at http://ssrn.com/abstract=954757 (last visited Dec. 31, 2007) (concluding that most major judicial campaign speech regulations are "of uncertain constitutionality" under White).

${ }^{98}$ Judge Rick A. Johnson, Judicial Campaign Speech in Kentucky After Republican Party of Minnesota v. White, 30 N. Ky. L. Rev. 347, 383-84 (2003) (quoting memorandum of Kentucky Judicial Conduct Commission).

${ }_{99}$ See Brian S. Faughnan \& Lucian T. Pera, Will Court's New Rules Help Tennessee Judicial Candidates Deal with Aftershocks of 'White' Decision?, TENN. B.J., June 2006, at 14, 20-21, 27.

${ }^{100}$ In re Amendment of Canon 7(B) (1) (c) of the Code of Judicial Conduct, 2002 Pa. LEXIS 3194, at*1 (Pa. Nov. 21, 2002) (adopting commit clause as replacement).

101 Smith v. Phillips, No. CIV.A.A-02CV111, 2002 WL 1870038, at *1 (W.D. Tex. Aug. 6, 2002). 
well beyond the announce clause. Some states substantially trimmed the prohibitions imposed by their commit clause ${ }^{102}$ or pledge or promise clause. ${ }^{103}$ Others more drastically reduced their regulation of campaign speech. North Carolina, for example, eliminated its pledges or promises clause, lifted its ban on candidates' personal solicitation of campaign contributions, and excluded misleading statements about a candidate's opponent from its misrepresent clause. ${ }^{104}$

The ABA's recent revisions to the Model Code also bear signs of grappling with the uncertain implications of White. A manifest response to White in the provisionally amended 2003 Code was to define "impartiality" and "impartial" as "absence of bias or prejudice in favor of, or against, particular parties or classes of parties, as well as maintaining an open mind in considering issues that may come before the judge." ${ }^{105}$ In addition, the new Code merged the commit clause with the pledges or promises clause, and simultaneously tightened the language of the latter. In place of the earlier ban on pledges or promises of conduct in office "other than the faithful and impartial performance of the duties of the office," 106 the Code tar-

102 See, e.g., Cal. Code of Judicial Ethics Canon 5B(1) (amended Dec. 22, 2003) (retaining ban on candidates' statements "that commit the candidate with respect to cases, controversies, or issues that could come before the courts" but rescinding prohibition on statements that "appear to commit" the candidate).

103 See, e.g., Approval of Amendments to the Tex. Code of Judicial Conduct, No. 02-9167 (Tex. Aug. 22, 2002), available at http://www.supreme.courts.state.tx.us/ MiscDocket/02/02916700.pdf (replacing ban on pledges or promises regarding judicial duties "other than the faithful and impartial performance of the duties of the office" with prohibition regarding "pending or impending cases, specific classes of cases, or specific propositions of law that would suggest to a reasonable person that the judge is predisposed to a probable decision within the scope of the pledge").

104 See N.C. Code of Judicial Conduct (amended Jan. 31, 2006). In the same action, the state also converted its admonition against "political activity inappropriate to [a judge's] judicial office" to permission to "engage in political activity consistent with [a] judge's status as a public official." Id. For another instance of a state's repealing major campaign speech restrictions, see Order Amending Preamble to Georgia Code of Judicial Conduct (Ga. Jan. 7, 2004), available at http://www.gasu preme.us/amended_rules/jqc_7_27_or.php (deleting Georgia's pledges or promises clause). In a contrary movement, legislators in a number of states initiated efforts to eliminate or curtail judicial elections; these efforts generally failed. See Friedland, supra note 97 , at 620 n.249 (summarizing attempts).

105 Model Code of Judicial Conduct Terminology (2003); see Hon. Howland W. Abramson \& Gary Lee, The ABA Model Code Revisions and Judicial Campaign Speech: Constitutional and Practical Implications, 20 TOuro L. REv. 729, 733 (2004) (attributing change to attempt "to eliminate the possibility that a future court would hold, like the majority in White, that 'impartiality does not adequately serve the interest of openmindedness."”) (citation omitted).

${ }_{106}$ Model Code of Judicial Conduct Canon 5A(3)(d)(i) (1990) (amended 2003). 
geted "pledges, promises, or commitments" concerning "cases, controversies, or issues . . . likely to come before the court" where such statements " are inconsistent with the [judge's] adjudicative duties." 107 Changes approved in the 2007 Code mark a further retreat from earlier restrictions, especially in the realm of political activities. Under the new rules, candidates for judicial office in partisan elections may identify themselves as candidates of a political organization, seek endorsements from political organizations, attend events sponsored by a political organization or candidate, establish a campaign committee, and communicate with the public through "any medium."

Most telling of White's impact, however, has been lower courts' receptiveness to attacks on other judicial campaign speech restrictions. A number of these are discussed below, ${ }^{109}$ but the fate of White itself on remand illustrates the trend. There, the Eighth Circuit confronted two provisions of Minnesota's canons that had not been addressed by the Supreme Court. The state's partisan activities clause had prohibited judicial candidates from identifying themselves as members of political organizations, attending political gatherings, or using endorsements. ${ }^{110}$ Its solicitation clause had barred candidates from personally soliciting or accepting campaign contributions and from personally soliciting publicly stated support. ${ }^{11}$ Considered "in light of White," both clauses were deemed to fail strict scrutiny. ${ }^{112}$

\section{THE FORECAST FOR CAMPAIGN SPEECH RESTRICTIONS: REASONS TO EXPECT ULTIMATE DEFEAT}

Alternative modes of reading the White opinion can account for the diverse assessments of its meaning. Parsed carefully, with emphasis on its qualifications and specific reach, the opinion implies tolerance of restrictions that lack the precise defects of the announce clause. Extrapolation of the opinion's central themes, on the other hand, points to a more ominous fate for most major campaign speech provisions. This Part argues that the flaw of a legalistic interpretation is not that it is illogical, but that its logic is too narrow. Viewing White through its essential outlook on judicial campaign

${ }^{107} I d$.

108 Model Code of Judicial Conduct R. 4.2(B)-(C) (2007).

109 See infra Part II.C.

110 Republican Party of Minn. v. White, 416 F.3d 738, 745 (8th Cir. 2005) (citation omitted).

${ }^{111} I d$. (citation omitted).

12 Id. at 766 . 
speech produces a more realistic picture than the stitching together of hopeful constructions of isolated passages. An understanding of the decision as signaling broader hostility toward campaign speech limitations is supported by the pattern of federal court rulings since White. Moreover, the ideological sympathies of the Court's majority appear to favor an expansive conception of judicial candidates' First Amendment rights. Should the Court thus deal harshly with other restrictions, White will join those decisions whose wider implications were plausibly resisted but ultimately confirmed.

\section{A. Competing Conceptions of White}

While the White Court was unequivocal in its rejection of the announce clause, a search for intimations of more tolerant positions on other restraints yields several possibilities. First, of course, is the scope of the holding; addressing only the announce clause, the opinion did not purport to resolve the validity of other provisions. ${ }^{113}$ In particular, the Court took pains to reserve questions concerning the commit clause $^{114}$ and the pledges or promises clause. ${ }^{115}$ Nor did the Court rule that future restrictions would necessarily be subjected to strict scrutiny. In reviewing the announce clause under that standard, the Court simply noted the parties' acceptance of strict scrutiny as the proper test. ${ }^{116}$ Even where strict scrutiny might be appropriate, the opinion contains indications that it would not inevitably prove fatal. For example, the Court cited two decisions that identified restrictions on political speech deemed narrowly tailored to serve a compelling state interest. ${ }^{117}$ Moreover, the opinion left open a substantial range of interests that might qualify as compelling. The Court expressly rejected only one of three meanings of "impartiality" as not

113 The Court declined to consider other restrictions on judicial campaign speech challenged by the plaintiffs. See Republican Party of Minn. v. Kelly, 534 U.S. 1054, 1054 (2001) (confining grant of certiorari).

114 See Republican Party of Minn. v. White, 536 U.S. 765, 774 n.5 (2002) ("We do not know whether the announce clause (as interpreted by state authorities) and the 1990 ABA canon [the commit clause] are one and the same. No aspect of our constitutional analysis turns on this question.”); see also Briffault, supra note 94, at 215 (stating that "[i]t is highly implausible to suggest that 'announce' and 'commit' mean the same thing").

115 The Court pointedly distinguished promises from announcements and noted that Minnesota's pledges or promises clause "is not challenged here." White, 536 U.S. at 780 .

116 Id. at 774; see infra Part II.B.2.

117 See White, 536 U.S. at 775, 782 (citing Brown v. Hartlage, 456 U.S. 45 (1982)); $i d$. at 786 (citing Burson v. Freeman, 504 U.S. 191 (1992)); see also infra notes 160-75 and accompanying text (discussing Brown and Burson). 
compelling, ${ }^{118}$ and did not foreclose consideration of other interests such as judicial independence ${ }^{119}$ and integrity. Finally, the White majority preserved the formal possibility of heightened regulatory authority in the sphere of judicial elections. In response to Justice Ginsburg's accusation that the majority had adopted a "unilocular, 'an election is an election,' approach," ${ }^{120}$ the Court declared that "we neither assert nor imply that the First Amendment requires campaigns for judicial office to sound the same as those for legislative office." ${ }^{121}$

In a sense, the doctrinal legacy of White rests on the meaning of this last disclaimer. To hopeful supporters of regulation, the passage hints at a willingness to countenance restrictions that, unlike the announce clause, are closely tailored to interests at stake in judicial elections. At least equally plausible, however, is a literal construction: viz., the case did not present an occasion for confronting whether speech principles developed for other elections must be generally imported into judicial races. ${ }^{122}$ That reading suggests the unprofitability of combing the opinion to detect what restrictions might technically fit within its interstices. In this view, the key to White's significance lies in its basic conception of judging and politics. That conception, it appears, is of judicial decisionmaking as not so fundamentally different from other government functions that its elections

118 See 536 U.S. at 775-78 (finding that "lack of preconception in favor of or against a particular legal view" is not a compelling interest but declining to determine weight either of "lack of bias for or against either party" to an action or of "openmindedness").

119 See J.J. Gass, Brennan CTR. FOR Justice, After White: Defending And Amending CANONS OF JUdiCIAL ETHICS 8 (2004), http://www.brennancenter.org/resources/ $\mathrm{ji} / \mathrm{ji} 4 . p d f$ (stating that while the White majority regarded the parties as having used "impartiality" and "independence" interchangeably, the two concepts "should not be conflated") (citing White, 536 U.S. at 775 n.6).

120536 U.S. at 805 (Ginsburg, J., dissenting).

121536 U.S. at 783.

${ }^{122}$ A comparison of City of Richmond v. J.A. Croson Co., 488 U.S. 469 (1989), and Adarand Constructors, Inc. v. Pena, 515 U.S. 200 (1995), provides an instructive example of how hollow this kind of qualification can be. Croson neither asserted nor implied that racial classifications by the federal government would be scrutinized as harshly as those by state and local government; on the contrary, the opinions of Justices O'Connor and Scalia explicitly distinguished between the two levels of government in considering action that distributes benefits and burdens based on race. See Croson, 488 U.S. at 489-90; id. at 521-22 (Scalia, J., concurring). Yet, Adarand-with the endorsement of both Justices-ruled that the Equal Protection Clause categorically required the same level of scrutiny for all racial classifications. Adarand, 515 U.S. at 227 (holding that "all racial classifications, imposed by whatever federal, state, or local governmental actor, must be analyzed by a reviewing court under strict scrutiny"). 
must be treated differently as well. Rather, elections for judges are still at bottom elections, and judicial candidates can claim substantially the same First Amendment protection as other participants in the legal arena. If this interpretation is correct, then White was only the first phase of the dismantling of judicial campaign speech regulation's prevailing structure.

\section{B. White's Denial of Judicial Exceptionalism}

Aside from its murky disclaimer, White betrays no consideration of modifying First Amendment principles for judicial elections. On the contrary, Justice Scalia's opinion regards the state as accepting the ordinary operation of those principles when it chooses a system of elected judges. The opinion finds nothing peculiar to the judicial enterprise that warrants lesser protection for judicial candidates' speech. This refusal to acknowledge judicial distinctiveness better explains the Court's application of strict scrutiny than the parties' stipulation to that standard. The vigor with which the standard is applied further displays the scant relevance of the judicial context, and suggests that most other restrictions would fare little better than the announce clause.

1. Judicial Candidates as Politicians Under the First Amendment

Prior to White, Professor Chemerinsky argued that when a state "make[s] . . judicial candidates into politicians by requiring them to run for office," they should have "the same basic right to free speech as all others standing for election." " While the Court's opinion did not embrace this position in so many words, its logic points overwhelmingly in that direction. Justice Ginsburg touched the heart of the majority's reasoning in objecting that "[j]udges are not politicians, and the First Amendment does not require that they be treated as politicians simply because they are chosen by popular vote." ${ }^{124}$ Like the court below, she obviously sympathized with the aim of speech restrictions "to prevent judicial campaigns from becoming routine political contests." ${ }^{25}$ The Court, however, squarely re-

${ }^{123}$ Chemerinsky, Restrictions, supra note 9, at 735.

124 White, 536 U.S. at 821 (Ginsburg, J., dissenting); see Lippman, supra note 96, at 140 (supporting campaign speech restrictions on ground that "a judge's duties are wholly distinguishable from those of any politician").

${ }^{125}$ Republican Party of Minn. v. Kelly, 247 F.3d 854, 880 (8th Cir. 2001); see also Symposium, Recent Changes in the Law of Judicial Elections, 56 MERCER L. REV. 815, 820- 
nounced immunity of judicial elections from "routine" First Amendment tenets. For the majority, imposition of speech restrictions for the campaign period "sets our First Amendment jurisprudence on its head." ${ }^{126}$ A state's decision to elect its judiciary entails acceptance of the broader constitutional conditions for all elections: "If the State chooses to tap the energy and the legitimizing power of the democratic process, it must accord the participants in that process . . the First Amendment rights that attach to their roles." ${ }^{127}$

While Justice Scalia's opinion did not draw on voting rights jurisprudence, the Court's approach to elections under the Equal Protection Clause supplies an instructive parallel. There, too, the Court confronted the state's choice to elect candidates to an office that could have been made appointive. Having chosen elections, the state is required to comply with the constitutional command of equality rather than withhold the franchise from those deemed insufficiently interested or qualified. ${ }^{128}$ It is true that the Court occasionally allows deviation from full equality for election to certain offices. ${ }^{129}$ In those instances, however, the Court contrasts the peculiarly narrow powers of the body involved to the more wide-ranging functions on which rigorous equality is premised. ${ }^{130}$ Justice Scalia in White, on the other hand, emphasized the similarities between judicial and legislative candidates for purposes of the First Amendment. ${ }^{131}$ He accused Jus-

21 (2005) [hereinafter Recent Changes] (asserting that "I have yet to talk to a practitioner, a lawyer, a judge, or a policy specialist" who does not believe that the distinction between judicial and other elections is "a very great one") (transcript remark of Barbara E. Reed). But see Swanson, supra note 87, at 103 (criticizing White dissenters as advocating view that " $[\mathrm{e}]$ lection campaigns deform judges into vote-seeking politicians").

${ }^{126}$ White, 536 U.S. at 781.

127 Id. at 788 (quoting Renne v. Geary, 501 U.S. 312, 349 (1991) (Marshall, J., dissenting)).

${ }^{128}$ See, e.g., Kramer v. Union Free Sch. Dist., 395 U.S. 621 (1969) (invalidating law that confined voting in school district elections to owners or lessees of taxable real property and parents or custodians of children in public schools).

${ }^{129}$ See, e.g., Ball v. James, 451 U.S. 355, 362-71 (1981) (upholding limitation of voting for directors of water district to landowners in proportion to number of acres owned); Salyer Land Co. v. Tulare Lake Basin Water Storage Dist., 410 U.S. 719 (1973) (upholding limitation on voting similar to those in Ball); see also Briffault, supra note 94, at 187-90 (arguing that such decisions furnish support for treating other judicial campaign speech restrictions differently from announce clause).

130 See, e.g., Salyer, 410 U.S. at 728.

131 Jacob McCrea, Comment, The First Amendment Allows a Candidate for Judicial Election to Announce His or Her Views on Disputed Legal or Political Issues: Republican Party of Minnesota v. White, 41 DuQ. L. REv. 425, 445 (2003) (endorsing White's premise that 
tice Ginsburg of "greatly exaggerat[ing] the difference between judicial and legislative elections." 132 Far from standing aloof from "representative government," he asserted, state-court judges participate through their power to "'make' common law" and to interpret state constitutions. ${ }^{133}$ Acting in this "policy making capacity," ${ }^{134}$ judges play an integral role in the representative enterprise. ${ }^{135}$ While a state may wish them to act more disinterested than other policymakers, it assumes the risk of real or perceived bias by subjecting them to elections. ${ }^{136}$

White makes clear, then, that judicial elections resemble other political contests enough to trigger the constitutional corollaries of the electoral process. These preeminently include the right of candidates to convey, and voters to receive, information relevant to the electorate's ability to make an informed choice. ${ }^{137}$ The opinion recites an earlier pronouncement that "debate on the qualifications of candidates' is 'at the core of our electoral process and of the First Amendment freedoms." " 138 Thus, under the First Amendment, the state may not "leav[e] the principle of elections in place while preventing candidates from discussing what the elections are about." ${ }^{139}$ Given the Court's acknowledgement of judicial policy formulation, these principles leave little disparity between judicial candidates' freedom to express their intentions and the platforms on which can-

judicial candidates "are not sufficiently different" from others "to justify a broad, content-based restriction on their freedom of speech during an election").

${ }^{132}$ White, 536 U.S. at 784.

133 Id. (quoting $i d$. at 806 (Ginsburg, J., dissenting)).

134 Id. 784 n.12.

135 See Snyder, supra note 48, at 244 (asserting that differences between judges and other public officials "ultimately ... are a matter of degree").

${ }^{136}$ See White, 536 U.S. at 792 (O'Connor, J., concurring) (stating that "[i]f the State has a problem with judicial impartiality, it is largely one the State brought upon itself" through the election of judges); see also Republican Party of Minn. v. Kelly, 247 F.3d 854, 886 (8th Cir. 2001) (Beam, J., dissenting) (indicating that Minnesotans' repeated insistence on popular control over the state's judiciary undermines the state's assertion of interest in independent judiciary).

${ }^{137}$ See White, 536 U.S. at 782 (stating that "[w]e have never allowed the government to prohibit candidates from communicating relevant information to voters during an election"); accord Buckley v. Valeo, 424 U.S. 1, 52-53 (1976) (stating that candidates for public office have a "right to engage in the discussion of public issues" and "to make their views known").

${ }^{138}$ White, 536 U.S. at 781 (quoting Eu v. San Francisco County Democratic Cent. Comm., 489 U.S. 214, 222-23 (1989)).

139 Id. at 788 . 
didates for other offices appeal to voters. ${ }^{140}$ Just as the electorate will want to know a legislative candidate's positions on the issues of the day, so too will it want to learn the views and values that would inform an aspiring judge's exercise of discretion. ${ }^{141}$ And as the Court noted, its curiosity will not be satisfied by abstractions like the candidate's commitment to "strict construction." ${ }^{142}$ To a large measure, judicial elections "are about" the candidates' differences on more specific questions. $^{143}$

\section{The Sweeping Scope of Strict Scrutiny}

The formal ambiguity surrounding White's broader framework includes the question of scrutiny. The Court's treatment of this issue bears quoting: "The Court of Appeals concluded that the proper test to be applied to determine the constitutionality of such a restriction is what our cases have called strict scrutiny; the parties do not dispute that this is correct." 144 On the surface, the opinion's adoption of strict scrutiny thus appears merely contingent. The opinion as a whole, however, points to the decision's establishment of strict scrutiny as the standard of review for all restrictions on judicial campaign speech.

To begin with, the Court's brief explanation does not necessarily mean that it applied strict scrutiny simply because the parties stipulated to that standard. ${ }^{145}$ Textually and logically, the passage could well reflect the Court's endorsement of strict scrutiny without elaboration due to lack of contention on this question. After all, it would seem curious even in this context for Justice Scalia to describe as "correct" a legal doctrine with which he disagreed. It seems even more unlikely that the Court would apply a standard that it considered inappropriate because that standard had the parties' support. A stipulation that racial classifications receive rationality review, for ex-

${ }^{140}$ See Allen, supra note 89, at 226 (lamenting that with the White decision, "the judicial branch is becoming more like the executive and legislative branch [sic]").

${ }^{141}$ See Grodin, supra note 14, at 1975 (1988) (criticizing the concept of "the judge as Hercules, eschewing all 'policy' judgments, and searching out and applying objectively ascertainable 'principles' inherent in the institutions and enactments of society"); Morrison, supra note 54, at 732 (describing judge's "basic values, principles, and preferences" as a "prism" through which a judge interprets authorities).

${ }^{142}$ See White, 536 U.S. at 773.

143 Id. at 788 .

144 Id. at 774 (citations omitted).

145 See In re Watson, 794 N.E.2d 1, 6 (N.Y. 2003) (arguing that the White Court "did not decide what level of review was applicable . . . but applied strict scrutiny because the parties agreed on that standard"). 
ample, would hardly be binding on the Court. On questions of federalism and separation of powers, the Court has not found decisive other branches' mutual acceptance of the allocation of authority. ${ }^{146}$ No obvious reason recommends itself for deferring to parties' understanding of proper scrutiny. Moreover, even if the Court were uncertain and applied a standard assuming arguendo that it was correct, selecting the most stringent review would clash with settled doctrines of constitutional adjudication. Where a statute's validity is in doubt, the Court has long favored paths that preserve the legislation; ${ }^{147}$ application of strict scrutiny in the face of ambivalence toward review would depart from this principle.

More broadly, the language of the opinion and the authority on which it rests reflect systemic adoption of strict scrutiny more than an ad hoc accession to the parties' view. At the outset of its analysis, the Court characterizes the announce clause as "prohibit[ing] speech on the basis of its content and burden[ing] a category of speech that is 'at the core of our First Amendment freedoms." ${ }^{148}$ This classification alone implicates constitutional traditions conferring the highest level of protection on speech. ${ }^{149}$ Indeed, the opinion relies heavily on decisions involving heightened scrutiny of restrictions on political speech $^{150}$ —so much so that Justice Ginsburg objected to the Court's

146 See, e.g., New York v. United States, 505 U.S. 144, 182 (1992) ("Where Congress exceeds its authority relative to the States . . . the departure from the constitutional plan cannot be ratified by the "consent' of state officials."); INS v. Chadha, 462 U.S. 919, 946-48 (1983) (striking down legislative veto provisions as violating requirement of presentment regardless of whether the president approved the statute).

${ }^{147}$ Crowell v. Benson, 285 U.S. 22, 62 (1932) (describing as "cardinal principle" that in such circumstances the Court "will first ascertain whether a construction of the statute is fairly possible by which the [constitutional] question may be avoided"), cited in Ashwander v. Tenn. Valley Auth., 297 U.S. 288, 346 (1936) (Brandeis, J., concurring).

${ }_{148} 536$ U.S. at 774 (quoting Kelly, 247 F.3d at 863).

149 See Ashcroft v. ACLU, 542 U.S. 656, 661 (2004) (stating that the Constitution "demands that content-based restrictions on speech be presumed invalid, and that the government bear the burden of showing their constitutionality") (citations omitted); United States v. Playboy Entm't Group, Inc., 529 U.S. 803, 813 (2000) (stating that since statute at issue is "a content-based speech restriction, it can stand only if it satisfies strict scrutiny") (citation omitted); Buckley v. Valeo, 424 U.S. 1, 14 (1976) (stating that First Amendment "affords the broadest protection" to "[d] iscussion of public issues and debate on the qualifications of candidates"); Monitor Patriot Co. v. Roy, 401 U.S. 265, 271 (1971) (stating that "it can hardly be doubted" that the First Amendment "has its fullest and most urgent application precisely to the conduct of campaigns for political office") (citation omitted); see generally ALEXANDER Meiklejohn, Free Speech and its Relation to SElf-Government (1948).

${ }_{150}$ See, e.g., White, 536 U.S. at 775, 781 (citing Eu v. San Francisco County Democratic Cent. Comm., 489 U.S. 214 (1989) (invalidating state's ban on political party 
"unrelenting reliance on decisions involving contests for legislative and executive posts." ${ }^{151}$ The Court's response, while repeating that judicial and legislative campaigns were not necessarily being equated, assumed the appropriateness of strict scrutiny:

[E]ven if the First Amendment allows greater regulation of judicial election campaigns than legislative election campaigns, the announce clause still fails strict scrutiny because it is woefully underinclusive .... We rely on the cases involving speech during elections only to make the obvious point that this underinclusiveness cannot be explained by resort to the notion that the First Amendment provides less protection during an election campaign than at other times. ${ }^{152}$

The opinion thus allows the possibility that judicial campaign restrictions could entail consideration of distinctive interests, but does not retreat from strict scrutiny in conducting that calculus. The stringency of that review far outweighs any concession to the relevance of the judicial setting. ${ }^{153}$

White's tenor bolsters the inference that it is adopting strict scrutiny for judicial campaign regulation generally. A pronounced skepticism of motive pervades the opinion. The Court mocked the argument that the state seeks to foster openmindedness and its appearance, ${ }^{154}$ and instead concluded that the real purpose of the announce clause is to undermine judicial elections. ${ }^{155}$ This exploration of actual motive, usually avoided in free speech challenges, ${ }^{156}$ is best explained by the presumptive invalidity of content-based restric-

endorsements of primary candidates)); Id. at 775, 782 (citing Brown v. Hartlage, 456 U.S. 45 (1982) (overturning state's nullification of election victory on grounds of candidate's impermissible campaign promises)); Id. at 782 (citing Wood v. Georgia, 370 U.S. 375 (1962) (reversing contempt conviction for criticism of grand jury investigation of alleged racial bloc voting in primary election)); Id. at 785, 787 (citing McIntyre v. Ohio Elections Comm'n, 514 U.S. 334 (1995) (invalidating statute banning distribution of anonymous political campaign literature)); $I d$. at 786 (citing Burson v. Freeman, 504 U.S. 191 (1992) (involving ban on campaigning within 100 feet of a polling place)).

${ }^{151}$ Id. at 806 (Ginsburg, J., dissenting).

${ }^{152} I d$. at 783 (majority opinion) (citation omitted).

153 See Buckley v. Ill. Judicial Inquiry Bd., 997 F.2d 224, 228 (7th Cir. 1993) (acknowledging that judges "remain different from legislators and executive officials . . . in ways that bear on the strength of the state's interest in restricting their freedom of speech" while invalidating state's announce clause and pledges or promises clause).

${ }_{155}$ See supra notes 71-72 and accompanying text.

155 See 536 U.S. at 782.

156 See City of Erie v. Pap's A.M., 529 U.S. 277, 292 (2000); United States v. O’Brien, 391 U.S. 367, 382-83 (1968). 
tions $^{157}$ under strict scrutiny. Nor does the opinion suggest that its willingness to conduct a probing review will be confined to its consideration of the announce clause in that case. Indeed, courts since White have widely assumed the applicability of strict scrutiny to a variety of restrictions on judicial campaign speech. ${ }^{158}$ Their belief further supports this construction as the natural reading of White.

\section{Strict Scrutiny's Devastating Effect}

Even assuming strict scrutiny, defenders of judicial campaign speech restrictions can argue that the White Court did not intend that standard to be "strict in theory but fatal in fact." 159 The Court's citation to two cases that describe means by which speech descriptions can survive strict scrutiny lends some credence to this position. As White itself demonstrates, however, regulation of judicial candidates' expression can generally be distinguished from the circumstances set forth in those opinions. More importantly, the key analytical elements of White's brand of scrutiny bode ill for most attempts to limit campaign speech.

\section{a. Unhelpful Precedent}

The Court in White perhaps unavoidably acknowledged its earlier decision in Burson v. Freeman. ${ }^{160}$ Applying strict scrutiny, the Burson Court found that Tennessee's ban on election-day campaigning around polling places was narrowly tailored to its compelling interests in shielding voters from "confusion and undue influence" and in pro-

157 See United States v. Playboy Entm't Group, Inc., 529 U.S. 803, 812-13 (2000); R.A.V. v. City of St. Paul, 505 U.S. 377, 382 (1992).

158 See, e.g., Republican Party of Minn. v. White, 416 F.3d 738, 749 (8th Cir. 2005) (applying strict scrutiny to prohibitions on certain partisan activities and personally soliciting campaign contributions); Weaver v. Bonner, 309 F.3d 1312, 1319 (11th Cir. 2002) (applying strict scrutiny to misrepresentation clause and bans on solicitation of campaign funds and publicly stated support); Kan. Judicial Watch v. Stout, $440 \mathrm{~F}$. Supp. 2d 1209, 1229-31, 1236-38 (D. Kan. 2006) (applying strict scrutiny to pledges or promises clause, commit clause, and provisions restricting solicitation of campaign contributions, publicly stated support, or signatures on nomination petitions); N.D. Family Alliance, Inc. v. Bader, 361 F. Supp. 2d 1021, 1036 (D. N.D. 2005) (applying strict scrutiny to commit and pledges or promises clauses).

159 White, 416 F.3d at 786 \& n.25 (8th Cir. 2005) (Gibson, J., dissenting) (citation and internal quotation marks omitted).

160504 U.S. 191 (1992), cited in Republican Party of Minn. v. White, 536 U.S. 765, 786 (2002). The Eighth Circuit pointed to Burson as "an example of the type of corroborating evidence that can support a speech restriction subject to strict scrutiny." Republican Party of Minn. v. Kelly, 247 F.3d 854, 879 (8th Cir. 2001). 
tecting the "integrity and reliability" of the electoral process. ${ }^{161}$ In distinguishing that outcome, the White Court did not argue that Tennessee's restriction on campaign speech presented a much closer fit between means and end than Minnesota's announce clause. Instead, the opinion emphasized an aspect of Tennessee's prohibition that the Burson majority had not: viz., the longstanding existence and widespread adoption of such bans. ${ }^{162}$ The Court's reliance on this distinction has ominous implications for much judicial campaign regulation. While the announce clause suffered from a lack of both popularity and longevity, ${ }^{163}$ other restrictions seem likely to suffer at least from the latter failing. In the Court's depiction, the "practice of prohibiting speech by judicial candidates on disputed issues"-a category that could be taken to include the pledges or promises and commit clauses- "is neither long nor universal."

Language from another case mentioned by the White Court, Brown v. Hartlage, ${ }^{165}$ offers comparably meager support to advocates of campaign speech limitations. The Court in Brown did acknowledge that "some kinds of promises made by a candidate to voters . . may be declared illegal without constitutional difficulty." 166 However, that is not the proposition for which Justice Scalia cited the decision in White. Rather, his opinion invoked Brown for its articulation of strict scrutiny ${ }^{167}$ and disapproval of governmental attempts to dictate the agenda of political campaigns. ${ }^{168}$ Moreover, the passage quoted has direct relevance only to the pledges or promises clause, and even there its potency is diluted by its status as dicta. In fact, the holding in Brown militates against restrictions; the Court overturned a state's voiding of an election based on the victor's having made a pledge that (unbeknownst to the candidate) state law would have barred him from fulfilling. ${ }^{169}$ Furthermore, the example of a proscribable promise furnished in Brown-to provide payment in exchange for

${ }^{161}$ Burson, 504 U.S. at 198-99.

162 Burson, 504 U.S. at 214-16 (Scalia, J., concurring), cited in White, 536 U.S. at 786-87.

163 White, 536 U.S. at 786.

164 Id. at 785 .

165456 U.S. 45 (1982); White, 536 U.S. at 775, 782 (citing Brown).

166 Brown, 456 U.S. at 55.

167 White, 536 U.S. at 775 (citing Brown, 456 U.S. at 45, 54).

168 White, 536 U.S. at 782 (citing Brown, 456 U.S. at 60).

169 Brown, 456 U.S. at 60-62. 
votes ${ }^{170}$-is far removed from the central concerns of the pledges or promises clause. $^{171}$

Finally, Justice Scalia's opinion implicitly dismisses the significance of one other line of authority to the cause of judicial campaign speech restrictions. The Eighth Circuit looked to Court decisions sustaining limits on campaign contributions, ${ }^{172}$ and others have also argued that the rationale of those holdings similarly supports limitations on judicial campaign expression. ${ }^{173}$ The Court in White did not trouble to rebut this analogy, but doubtless could have done so. For example, it could have found that the actual and perceived corruption spawned by unrestrained campaign donations finds no counterpart in the effects of judicial candidates' representations. ${ }^{174}$ To the extent that tension exists between these doctrines, however, it seems likely that the Court's protection of freedom to participate in political campaigns will prevail. ${ }^{175}$

\section{b. The Slim Roster of Compelling Interests}

White displays both a narrow conception of impartiality and resistance to treating other interests as compelling. The prospects of a campaign speech limitation at issue are therefore clouded even before the question of narrow tailoring is considered. While the Court implied that preventing bias for or against a party qualifies as compelling, ${ }^{176}$ the opinion takes a strenuously literal view of that interest. Justice Scalia emphatically distinguished between bias toward parties and bias concerning issues, ${ }^{177}$ and left no doubt that a candidate was entitled to exhibit the latter. Although a party advancing a position

$170 \quad$ Id. at 54

171 See infra Part III.B.

172 Republican Party of Minn. v. Kelly, 247 F.3d 854, 878-79 (8th Cir. 2001) (citing Nixon v. Shrink Mo. Gov't PAC, 528 U.S. 377 (2000); Buckley v. Valeo, 424 U.S. 1 (1976) (per curiam)); see also Austin v. Michigan Chamber of Commerce, 494 U.S. 652 (1990) (upholding prohibition on use of corporate funds to support or oppose any candidate for state office).

${ }^{173}$ See, e.g., Briffault, supra note 94 , at 190, 201-02, 212-13, 225, 228, 231-32. In addition to the cases noted at supra note 172, Briffault discusses McConnell v. FEC, 540 U.S. 93 (2003), decided the term after White.

${ }_{174}$ See Austin v. Mich. Chamber of Commerce, 494 U.S. 652, 659-60 (1990); Buckley, 424 U.S. at 26-27 (per curiam); Friedland, supra note 97, at 611.

${ }_{175}$ See Ronald D. Rotunda, Judicial Elections, Campaign Financing, and Free Speech, 2 ELECTION L.J. 79, 80-81 (2003) (suggesting that White "casts a long shadow" over campaign finance laws).

${ }_{176}$ See White, 536 U.S. at 775-76 (noting cases in which impartiality in the sense of judge's lacking this bias was found "essential to due process").

Id. at 776 . 
adverse to that taken by the judge as a candidate can anticipate defeat of that position, this result does not show animosity or favoritism toward a particular party; " $[a] n y$ party taking that position is just as likely to lose." 178 The Court thus effectively rejected the argument that a judicial candidate's stance on an issue can amount to bias against parties because it implies prejudice against a class of litigants. ${ }^{179}$

The White Court seemed equally disinclined to regard the appearance of impartiality, however understood, as a freestanding compelling interest. Rather, any stake in maintaining that interest seems strictly derivative of the substantive interest with which the image of impartiality is associated. After determining that lack of preconception toward a legal view did not deserve recognition as a compelling interest, the Court dismissively rejected the state's interest in the appearance of such neutrality; there would be no point in "pretending" that this type of impartiality is worthy of preservation. ${ }^{180}$ In contrast, the dissenting opinions dwelt on the importance of "the public's confidence in the integrity and impartiality" of the courts ${ }^{181}$ and of their "reputation for impartiality and openmindedness." 182

The prospects for reliance on judicial independence as a compelling interest are apparently likewise dim. First, it is not even clear that the White majority considered independence to be a discrete interest apart from impartiality. At least in the litigation before it, the Court perceived the two terms as employed interchangeably. ${ }^{183}$ Even if judicial independence is granted to exist separate and distinct from impartiality, ${ }^{184}$ the Court is unlikely to ascribe much weight to that interest in this context. ${ }^{185}$ Justice Scalia's opinion implies that the state

$178 \quad$ Id. at 777

179 See id. at 799-800 (Stevens, J., dissenting) (advancing this argument); GASs, supra note 119, at 6-7 (offering example that "[a] woman in a custody battle standing before a judge who declared in his election campaign that 'men get too many raw deals in custody rulings' cannot be comforted by the thought that this is merely a bias 'on an issue'"); Morris, supra note 97, at 7 (suggesting that a judicial candidate's "promising to make a corporation pay for its 'greed' in producing a defective product" is problematic but may be protected by distinction between party bias and issue bias).

180 White, 536 U.S. at 778.

181 Id. at 817 (Ginsburg, J., dissenting).

182 Id. at 802 (Stevens, J., dissenting).

183 See id. at 775 n.6 (majority opinion).

184 See supra notes 118-22 and accompanying text.

185 Cf. Dale A. Riedel, Note, Losing Faith in the System: Unfettered Political Speech of Judicial Candidates Fails to Assure an Openminded Judiciary After Republican Party of 
has already compromised, if not forfeited, a strong interest in judicial independence by holding judges accountable to voters. For example, he rejects the argument that the announce clause shields judges from compulsion to conform their rulings to campaign pronouncements, observing that "elected judges-regardless of whether they have announced any views beforehand-always face the pressure of an electorate who might disagree with their rulings and therefore vote them off the bench." 186 Nor should proponents of restrictions expect the Court's to be receptive of arguments invoking other interests such as judicial integrity. Even a notable defender of campaign speech restraints has conceded that it is dubious to single out judges' integrity as requiring protection through curbs on political expression. ${ }^{187}$

\section{c. The Alternative of Recusal}

As noted earlier, the White Court did not determine the weight of the state's interest in judicial openmindedness because the announce clause did not seem designed to achieve that purpose. ${ }^{188}$ The opinion's sparse references to the nature of this interest offer little encouragement that the Court would consider it compelling. Justice Scalia characterized this meaning of impartiality as "not a common one," and allowed only that openmindedness and its appearance "may well be ... desirable in the judiciary." 189 Even assuming that openmindedness qualifies as compelling, however, it would be difficult to craft campaign speech restrictions narrowly tailored to serve that interest. Two obstacles in particular stand in the way: the availability of disqualification or recusal as a less restrictive alternative, and the dilemma posed by the Court's approach to underinclusiveness.

Justice Kennedy's concurrence hints at why speech restrictions may be found unnecessary to foster openmindedness or any other interest championed by the state. While spurning state attempts to "censor what the people hear" about judicial candidates, Justice Kennedy recognized its power to "adopt recusal standards more rigorous than due process requires." ${ }^{190}$ Under this line of reasoning, even the

Minnesota v. White, 28 U. DAYTON L. REv. 421, 437 (2003) (citing instances of

Court's recognizing importance of judicial independence in other contexts).

${ }^{186} 536$ U.S. at 782.

187 See Briffault, supra note 94, at 220.

188 See supra notes 71-72 and accompanying text.

189536 U.S. at 778.

${ }^{190}$ Id. at 794 (Kennedy, J., concurring). Traditionally, "recusal” refers to a judge's voluntary removal from a case, while "disqualification" results from a party's motion 
suppression of campaign expression deemed incompatible with openmindedness or its appearance would not pass strict scrutiny. Instead, a judge whose campaign statement betrayed implacable bias could be replaced by an openminded judge as an alternative less restrictive of speech. ${ }^{191}$ Admittedly, recusal may operate as a less than ideal solution. The standards governing recusal and disqualification can be hazy, ${ }^{192}$ parties may be deterred from seeking reassignment by fear of alienating the judge if unsuccessful, and a regime of liberal disqualification could generate substantial costs. ${ }^{193}$ Moreover, provisions patterned after the ABA Model Code, disqualifying a judge from a case if the judge's impartiality "might reasonably be questioned," ${ }^{194}$ may be challenged on grounds of overbreadth ${ }^{195}$ or chilling political expression ${ }^{196}$ if applied to campaign speech. Still, courts since White have cited the availability of recusal as obviating the need for speech restrictions, ${ }^{197}$ while recusal provisions like that in the Model Code have withstood facial challenges. ${ }^{198}$

to require the judge's removal. Richard E. Flamm, JUdicial DisQualification: RECUSAL AND DisQUALIFICATION OF JUDGES 4-5 (1996). Justice Kennedy apparently used "recusal" to encompass both actions; this Article uses the term in both senses according to context.

191 See Friedland, supra note 97, at 613-14; see also Joanna Cohn Weiss, Note, Tough on Crime: How Campaigns for State Judiciary Violate Criminal Defendants' Due Process Rights, 81 N.Y.U. L. REV. 1101, 1126-35 (2006) (arguing for mandatory recusal in criminal cases of judges who conducted "tough-on-crime" election campaigns); In re Enforcement of Rule 2.03, Canon 5.B(1) (c), Campaign Conduct (Mo. July 18, 2002) (en banc), available at http://www.courts.mo.gov (search "campaign conduct") (stating that recusal or disqualification may be required "in cases that involve an issue about which the judge has announced his or her views").

192 See Monroe H. Freedman \& Abbe Smith, Understanding Lawyers' Ethics § 9.06 (2d ed. 2002).

193 See Friedland, supra note 97 , at 614.

194 Model Code of Judicial Conduct R. 2.12(A) (1990) (amended 2003).

195 See Abramson \& Lee, supra note 105, at 733-34; see also Matthew D. Besser, Note, May I Be Recused? The Tension Between Judicial Campaign Speech and Recusal After Republican Party of Minnesota v. White, 64 OHIO ST. L.J. 1197, 1218-25 (2003) (arguing that judges are not required to recuse themselves from cases involving issues that they permissibly addressed during campaign).

196 See Matthew J. Medina, Note, The Constitutionality of the 2003 Revisions to Canon 3(E) of the Model Code of Judicial Conduct, 104 Colum. L. REv. 1072, 1073, 1102-07 (2004) (arguing that the provision in the 2003 ABA Model Code requiring disqualification of a judge who has made any "public statement that commits, or appears to commit, the judge with respect to" an "issue" or "controversy" in a case is impermissibly overbroad and vague) (citation omitted).

${ }^{197}$ See, e.g., Republican Party of Minn. v. White, 416 F.3d 738, 755 (8th Cir. 2005); Kan. Judicial Watch v. Stout, 440 F. Supp. 2d 1209, 1231, 1234-35 (D. Kan. 2006); N.D. Family Alliance, Inc. v. Bader, 361 F. Supp. 2d 1021, 1042 (D.N.D. 2005); 


\section{d. Underinclusiveness and the Overbreadth Quandary}

Even if legal and practical barriers undermine recusal's utility, another aspect of the White Court's reasoning will likely thwart restrictions intended to safeguard against threats to openmindedness. As noted earlier, the incongruity between the aim of ensuring openmindedness and the scope of Minnesota's ban on announcing views left the Court unwilling to ascribe this purpose to the rule. ${ }^{199}$ In barring announcements "only at certain times and in certain forms," 200 the rule left judges and aspiring judges free to state their views in a wide range of forums similarly incompatible with judicial openmindedness. ${ }^{201}$ The condemnation of underinclusiveness here contrasts with a more tolerant approach taken by the Court elsewhere. ${ }^{202}$ In particular, the Court rejected the contention that the ban's selectivity was justified by the uniquely heightened threat to openmindedness posed by campaign statements. ${ }^{203}$

This robust notion of underinclusiveness augurs poorly for other restrictions, especially the commit clause. Like the announce clause, the commit clause targets statements during the campaign while allowing expressions of commitment outside the period of candidacy. ${ }^{204}$ In addition, although White did not address the commit clause, its

Spargo v. N.Y. State Comm'n on Judicial Conduct, 244 F. Supp. 2d 72, 88-89 (N.D.N.Y. 2003), rev'd on other grounds, 351 F.3d 65 (2d Cir. 2003).

198 See, e.g., Ala. Right to Life Political Action Comm. v. Feldman, 380 F. Supp. 2d 1080, 1083-84 (D. Ala. 2005); N.D. Family Alliance, Inc., 361 F. Supp. 2d at 1036 (D.N.D. 2005); Family Trust Found. of Ky., Inc. v. Wolnitzek, 345 F. Supp. 2d 672, 705-10 (E.D. Ky. 2004).

${ }^{199}$ See supra notes 71-72 and accompanying text.

200 Republican Party of Minn. v. White, 536 U.S. 765, 783 (2002).

201 See id. at 779-80; see also Snyder, supra note 48, at 230 (objecting that restriction of campaign speech "prohibits one type of public pronouncement of judicial candidates but ignores numerous other types of public pronouncements that may have equal or greater impact on judicial impartiality").

202 See, e.g., Ladue v. Gilleo, 512 U.S. 43, 51-53 (1994); City Council v. Taxpayers for Vincent, 466 U.S. 789, 810-11 (1984).

203 White, 536 U.S. at 780-81; see S. Graham Simmons III, Note, "I am Pro-Choice, Pro-Union and I Oppose Capital Punishment-I Want You to Elect Me to the Pennsylvania Supreme Court": Is this the Future of Pennsylvania's Judicial Elections?, 48 VILL. L. REV. 911, 948 (2003) (asserting that "[o]ne cannot truly expect to preserve public confidence in judicial impartiality when judges are prohibited from announcing their views on divisive issues solely during election campaigns"). But see Bogard, supra note 91, at 14 (asserting that statements made "during the heat of a campaign" are "light years away from those made at any other time").

204 See Begaye, supra note 96, at 467 (stating that the commitment clause "does not cast the net wide enough to include within its prohibitions persons who have or will commit themselves to issues before and after a judicial election"). 
prospects appear darkened by Justice Scalia's choice of words in underlining the incomplete reach of the announce clause: "Before they arrive on the bench . . . judges have often committed themselves on legal issues that they must later rule upon." ${ }^{205}$ Bans on partisan activities during a campaign appear similarly susceptible to charges of underinclusiveness. ${ }^{206}$ The pledges or promises clause, on the other hand, may be somewhat less vulnerable to this attack; the White Court granted the possibility that promissory statements during a campaign may carry a special resonance with voters. ${ }^{207}$ Even that concession, however, hardly amounted to an unqualified endorsement. Rather, the Court acknowledged that it "might be plausible, perhaps," that campaign promises present a special danger to openmindedness. ${ }^{208}$ Besides other potential problems with the pledges or promises clause ${ }^{209}$ it is not hard to envision the Court's identifying promises beyond the clause's proscription that arguably jeopardize openmindedness. For example, the clause does not forbid expression by third parties that could be construed as a pledge on behalf of a candidate to rule in a particular way. Of course, pledges or promises by third parties presumably do not bind a candidate in the public's eyes as firmly as do the candidates' own statements. However, given the White Court's cynical view of campaign promises- "the least binding form of human commitment" ${ }^{\text {"10 }}$ - that difference might be considered slight. ${ }^{211}$ Moreover, experience with political advertisements by "independent" committees does not encourage confidence in voters' ability to distinguish between statements authorized by a candidate and those sponsored by others. ${ }^{212}$

205 White, 536 U.S. at 779 (emphasis added).

206 See Republican Party of Minn. v. White, 416 F.3d 738, 758 (8th Cir. 2005) (finding underinclusive a regulation "requiring a candidate to sweep under the rug his overt association with a political party for a few months during a judicial campaign, after a lifetime of commitment to that party"); Begaye, supra note 96, at 470 (asserting that the political activity clause suffers from the same type of underinclusiveness as Minnesota's announce clause).

207 See White, 416 F.3d at 780.

208 Id.

209 See infra Part III.B.

210536 U.S. at 780.

211 Gillers, supra note 46, at 732-33 (disputing the distinction between candidate speech and speech of third parties as grounds for restricting judicial candidates' freedom to speak about particular legal issues).

212 See Eric W. Groenendyk \& Nicholas A. Valentino, Of Dark Clouds and Silver Linings: Effects of Exposure to Issue Versus Candidate Advertising on Persuasion, Information Retention, and Issue Salience, CommC'N REs., June 2002, at 295, 299; David B. Magleby, Dictum Without Data: The Myth of Issue Advocacy and Party Building (2001), 
A finding of underinclusiveness is devastating for judicial campaign speech restrictions because the theoretical cure for this defect is not available in practice. In principle, underinclusiveness can be remedied by the imposition of a more comprehensive restriction. With judicial campaigning, however, extending restraints on candidates' speech would inevitably produce impermissible overbreadth. The White opinion's examples of relevant speech, untouched by the announce clause, show the impossibility of widely banning threats to openmindedness without infringing heavily on protected expression. As the Court noted, the clause left judicial candidates free to announce their views on legal issues in books, speeches, classes that they teach, and-in the case of sitting judges-even prior judicial opinions. It is inconceivable, of course, that a state could forbid or even contemplate forbidding all these modes of expression. Indeed, in the case of the announce clause, it would be impossible to expunge statements of views that a judicial candidate innocently made prior to pursuing office. Likewise, it would be absurd to require of judicial candidates either that they had never engaged in partisan activity or that they somehow retroactively repudiate such behavior. Again, the case for the pledges or promises clause is somewhat closer; candidates would presumably issue no meaningful promises before launching their campaign. However, if the Court did find even that clause underinclusive for failure to cover third parties as noted above, expanding the clause's scope to encompass those promises would raise serious First Amendment concerns. Thus, most, if not all, significant restrictions on judicial campaign speech will likely be caught between the Scylla of overinclusivness and the Charybdis of overbreadth. ${ }^{213}$

http://csed.byu.edu/Publications/Dictum.doc, at 1, 11 (finding that audience's "clear perception is that election issue ads come from candidates or parties and not from interest groups").

${ }^{213}$ The quandary arising from White's approach to underinclusiveness resembles the implications of criticism of a race-conscious admissions program by dissenters in Grutter v. Bollinger, 539 U.S. 306 (2003). In an opinion expressing the views of four of the five justices in the White majority, Chief Justice Rehnquist voiced incredulity that the University of Michigan Law School's attention to race and ethnicity could be explained by its professed goal of achieving "critical mass" for underrepresented minorities in its student body. Id. at 379 (Rehnquist, C.J., joined by Scalia, Kennedy, and Thomas, J.J., dissenting). As proof, he pointed to marked disparities over a sixyear period in the number of African-American, Hispanic, and Native American applicants admitted to the school. Id. at 381-86. In a sense, the dissenters regarded failure to extend the relatively generous admission of African-Americans to the latter two groups as tellingly "underinclusive." At the same time, however, it is unimaginable that these justices would have approved a commitment to admitting all three groups in numbers similar to those of admitted African-American applicants during 


\section{Lower Court Auguries}

Commentators who favor restrictions on judicial campaign speech can indulge their optimism about the possibilities for restraints conceivably left by White. Judges confronted with actual cases and the prospect of reversal, however, must take a clear-eyed look at the underlying message of that decision. In federal courts, they have overwhelmingly found challenged restrictions to violate White's command. While consensus among federal courts does not inevitably presage Court holdings, ${ }^{214}$ there is no reason here to believe that lower courts have routinely misread the White Court's intent. Rather, this striking pattern reinforces the logical interpretation of Justice Scalia's opinion as signaling broad opposition to limitations on judicial candidates' speech. As already noted, lower courts have generally embraced the most speech-protective interpretations of White: categorical strict scrutiny, ${ }^{215}$ reliance on recusal as a substitute for limiting speech, ${ }^{216}$ and rigorous application of the underinclusiveness doctrine. ${ }^{217}$ This searching review has resulted in the invalidation of numerous state campaign provisions: the commit clause, ${ }^{218}$ the pledges or promises clause, ${ }^{219}$ the solicitation clause, ${ }^{220}$ the partisan activities clause, ${ }^{221}$ and the misrepresentation clause. ${ }^{222}$ The adverse tenor of

that period. Instead, such an admissions policy would doubtless have been condemned as an invalid "quota." See, e.g., id. at 389 (Kennedy, J., dissenting) (equating "critical mass" with "quotas"). Thus, in both settings a strong version of underinclusiveness appears to place the state in a pincer between going too far and not going far enough.

${ }^{214}$ See, e.g., Cent. Bank of Denver v. First Interstate Bank of Denver, 511 U.S. 164 (1994) (rejecting unanimous view of eleven courts of appeals that $\S 10$ (b) of the Securities and Exchange Act of 1934 authorizes private actions for aiding and abetting in violation of the section's prohibitions).

${ }^{215}$ See supra Part II.B.2.

216 See supra Part II.B.3.c.

217 See supra Part II.B.3.d.

218 See, e.g., Kan. Judicial Watch v. Stout, 440 F. Supp. 2d 1209, 1228-35; Ala. Right to Life Political Action Comm. v. Feldman, 380 F. Supp. 2d 1080, 1083 (D. Ala. 2005); N.D. Family Alliance, Inc. v. Bader, 361 F. Supp. 2d 1021, 1042 (D.N.D. 2005); Family Trust Found. of Ky., Inc. v. Wolnitzek, 345 F. Supp. 2d 672, 696-704 (E.D. Ky. 2004).

${ }^{219}$ See, e.g., Stout, 440 F. Supp. 2d at 1228-35; Feldman, 380 F. Supp. 2d at 1080, 1083; Bader, 361 F. Supp. 2d at 1042; Wolnitzek, 345 F. Supp. 2d at 696-704.

${ }^{220}$ See, e.g., Republican Party of Minn. v. White, 416 F.3d 738, 763-66 (8th Cir. 2005); Weaver v. Bonner, 309 F.3d 1312, 1319-23 (11th Cir. 2002); Stout, 440 F. Supp. 2d at 1235-38.

${ }_{221}$ See, e.g., Spargo v. N.Y. State Comm'n on Judicial Conduct, 244 F. Supp. 2d 72, 88-90 (N.D.N.Y.), rev'd on other grounds, 351 F.3d 65 (2d Cir. 2003).

${ }^{222}$ Weaver, 309 F.3d at 1319-22. 
these courts' decisions often highlights their dissatisfaction with the restrictions before them. On remand, for example, the Eighth Circuit found that Minnesota's solicitation and political activities clauses operated not just to dampen but to "kill" rights of association and political speech. ${ }^{223}$

It is true that some courts have not shied from enforcing campaign limitations since White; the source of this support, however, offers small comfort to proponents of restrictions. In a pair of companion cases, the New York Court of Appeals sustained the constitutionality of the state's pledges or promises clause ${ }^{224}$ and political activities clause. ${ }^{225}$ Shortly before, the Florida Supreme Court similarly denied challenges to its commit clause and pledges or promises clause. ${ }^{226}$ The obvious link among these holdings is that, in contrast to the above-cited decisions invalidating restrictions, they were issued by state supreme courts. ${ }^{227}$ Of course, the determinations of state court judges are not inherently suspect when they clash with those of federal counterparts. In this instance, however, a sound basis exists for crediting the federal judiciary with a more dispassionate view of constitutional doctrine. State high courts typically promulgate the very canons of judicial conduct whose legitimacy they adjudicate, ${ }^{228}$ as occurred in the New York and Florida cases. ${ }^{229}$ It would be natural for them to confer an exceptionally high presumption of validity on their handiwork. Federal courts, on the other hand, have no such psychological or institutional investment in the campaign speech restraints that they review. Accordingly, their nearly uniform rejection of restrictions since White should receive comparatively greater weight.

White, 416 F.3d at 746.

${ }^{224}$ In re Watson, 794 N.E.2d 1, 5-8 (N.Y. 2003) (per curiam).

225 In re Raab, 793 N.E.2d 1287, 1290-93 (N.Y. 2003).

${ }^{226}$ In re Kinsey, 842 So. 2d 77, 85-87 (Fla. 2003).

227 See also In re Dunleavy, 838 A.2d 338, 351 (Me. 2003) (Maine Supreme Judicial Court's upholding a provision forbidding sitting judges to solicit support for political candidates or purchasing tickets to political dinners or functions).

${ }^{228}$ See James Duke Cameron, The Inherent Power of a State's Highest Court to Discipline the Judiciary, 54 CHI.-Kent L. Rev. 45, 52-53 (1977).

229 See In re Code of Judicial Conduct, 643 So. 2d 1037 (Fla. 1994); N.Y. RulEs OF Judicial CONDUCT (codified at N.Y. CoMP. R. \& REGS. tit. 22, § 100 (2006)) . 


\section{The Majority's Hostility to Campaign Speech Restrictions: A Realistic Assessment}

One of the striking features of Justice Scalia's opinion in White is his uncharacteristic ${ }^{230}$ observation that judges actively shape law. ${ }^{231}$ While this acknowledgement supports allowing judicial candidates to share their views with voters, it also invites inquiry into how the Justices' own views might influence doctrine in this area. Much commentary on differences over campaign speech restrictions is couched in elegant terms of competing analytical models. ${ }^{232}$ However, an examination of the main beneficiaries of liberalized campaign codes suggests that personal preferences may help to account for some Justices' stance on speech restrictions. Specifically, removal of restraints on campaigning predominantly favors conservative causes to which a number of Justices may be sympathetic. The thesis of this Article does not hinge on this explanation. However, if correct, this hypothesis reinforces other evidence that most significant restrictions will ultimately fail. Though it is arguably unseemly to engage in such speculative nose-counting, the exercise belongs to the same tradition of legal realism ${ }^{233}$ that Justice Scalia invoked to recognize judicial policymaking. If law is-to quote an early articulation of this tradition-" $\mathrm{t}]$ he prophecies of what the courts will do in fact, and nothing more pretentious," ${ }^{234}$ a full understanding of the law of campaign speech codes will include consideration of this possibility. ${ }^{235}$

${ }^{230}$ Justice Scalia has championed the view that judges should interpret law by consulting objective sources rather than injecting their personal views. See, e.g., Antonin Scalia, Originalism: The Lesser Evil, 57 U. CinN. L. Rev. 849, 863-64 (1989) (arguing in favor of originalism as method of interpreting Constitution on ground that it "establishes a historical criterion that is conceptually quite separate from the preferences of the judge himself").

${ }^{231}$ See supra notes 133-36 and accompanying text.

232 See, e.g., Michael Richard Dimino, Sr., Counter-Majoritarian Power and Judges' Political Speech, 58 FLA. L. REV. 53, 55 (2006) (arguing that split among Justices in White can be explained by sharply clashing approaches to the "counter-majoritarian difficulty"); Sparling, supra note 96, at 445, 455 (characterizing debate between majority and dissenters over appearance of impartiality as clash between "revisionist" and "traditionalist" camps); Leading Cases, 116 HARV. L. REV. 200, 276-78 (2002) (contrasting majority's "antifunctionalist" approach to free speech analysis with dissenters' "functionalist" approach).

233 See generally Wilfred E. Rumble, JR., American Legal REAlism: Skepticism, REFORM, AND THE JUdiCIAL PROCESS (1968).

${ }^{234}$ Oliver Wendell Holmes, Jr., The Path of the Law, 10 HaRv. L. REv. 457, 461 (1897).

235 Notwithstanding Justice Scalia's formalism, see supra note 230, his authorship of the Court's opinion in White makes this investigation perhaps particularly apt. Justice Scalia obviously believes that constitutional interpretation can be heavily influ- 
Although White was perceived in some quarters as an attack on judicial elections themselves, ${ }^{236}$ close inspection of the decision does not support this interpretation. Justice O'Connor's review of the dangers of elections may amount to criticism, ${ }^{237}$ but the majority opinion that she joined does not question the integrity of the practice. On the contrary, it was the announce clause's "electionnullifying effect" ${ }^{\prime 238}$ that rendered this restriction defective. Formally agnostic on the mode of selecting judges, the Court was adamant about the ground rules for elections in the states that choose to conduct them. Given persistent voter sentiment to retain elective judgeships, ${ }^{239}$ the holding had the effect of aiding groups that would benefit from a less inhibited style of judicial campaigning. As described below, these have typically been groups that would generally be regarded as conservative. ${ }^{240}$ Whether this correlation has influenced Justices' positions on judicial candidates' rights is of course a matter of conjecture. $^{241}$ The phenomenon of recurring challenges to campaign speech restraints by advocates of conservative interests, however, is unmistakable.

It is widely agreed that White galvanized special interest groups to press judicial candidates for their positions on controversial issues. ${ }^{242}$ In principle, these efforts could be waged by organizations of all ideological stripes; in practice, they have overwhelmingly involved groups of a decidedly conservative cast. In North Dakota Family Alliance, Inc. $v$.

enced by personal preferences, as he has charged colleagues with succumbing to this temptation on numerous occasions. See, e.g., Kansas v. Marsh, 126 S. Ct. 2516, 2532 (2006) (Scalia, J., concurring); United States v. Virginia, 518 U.S. 515, 585-86 (1996) (Scalia, J., dissenting).

${ }^{236}$ See, e.g., Sherrilyn A. Ifill, Through the Lens of Diversity: The Fight for Judicial Elections After Republican Party of Minnesota v. White, 10 MiCH. J. RACE \& L. 55, 56-57 (2004); Sarah Frisque, Note, Preventing Mudslinging in Chambers: Alternatives After the Demise of the Announce Clause in Republican Party of Minnesota v. White, 26 HamLInE L. REV. 415, 416-17, 462 (2003).

${ }^{237}$ See White, 536 U.S. at 788-92 (O’Connor, J., concurring).

238536 U.S. at 782 (majority opinion).

239 See supra notes 32-34 and accompanying text.

240 Even in the political arena, the terms "conservative" and "liberal" cannot be defined with comprehensive precision. However, their popular usage, including allied polarities like "red state" and "blue state," reflects a widespread perception that at least some salient social and political issues can be helpfully understood as eliciting divisions between these two camps. The examples employed in this section, it is felt, are associated with identifiable conservative and liberal attitudes.

241 See infra notes 261-87 and accompanying text.

242 See, e.g., Roger J. Miner, Judicial Ethics in the Twenty-First Century: Tracing the Trends, 32 HOFSTRA L. REV. 1107, 1112 (2004); White, supra note 19, at 623. 
Bader, ${ }^{243}$ for example, the petitioner organization alleged that the state's commit and pledges or promises clauses interfered with its ability to obtain answers to its questionnaires from judicial candidates. The Alliance, which promotes socially conservative beliefs, ${ }^{244}$ asked candidates to register their agreement or disagreement with such propositions as "the North Dakota Constitution does not recognize a right to homosexual sexual relationships," "the North Dakota Constitution does not recognize a right to abortion," and the Supreme Court's ruling that school-sponsored prayer at school athletic events violates the Establishment Clause ${ }^{245}$ "was incorrectly decided . . . ." ${ }^{246}$ Other suits by groups with missions like the Alliance's have also been brought for the purpose of learning candidates' views on social and religious issues. Again, the nature of the beliefs that candidates were asked to affirm or dispute reflected distinctly conservative positions on these issues: e.g., "[t]he unborn child is biologically human and alive and ... the right of human beings should be respected at every stage of their biological development," ${ }^{247}$ and "the Kentucky Constitution does not require that same-sex couples be permitted to enter into civil unions that encompass those state rights that attach to legal marriage." ${ }^{248}$ While surveys of judicial candidates are not the exclusive province of the right, ${ }^{249}$ recent campaigns have continued to indicate disproportionate activity from this part of the ideological spectrum. ${ }^{250}$

243361 F. Supp. 2d 1021 (D.N.D. 2005).

244 See Dale Wetzel, Group Wants Marriage Defined in Constitution, BismarCK TRIBUNE, May 26, 2004, at 1.

${ }_{245}$ Santa Fe Indep. Sch. Dist. v. Doe, 530 U.S. 290 (2000).

246 N.D. Family Alliance, Inc. v. Bader, 361 F. Supp. 2d 1021, 1028 (D. N.D. 2005).

247 Kan. Judicial Watch v. Stout, 440 F. Supp. 2d at 1217; Judge: Wisconsin Judicial Ethics Rules Will Hold During Campaign, Associated Press, 2007, available at http://www.winonadailynews.com/articles/2007/02/14/wi/06winews0214.txt (discussing anti-abortion group's challenge of state's prohibition on promises in order to learn candidates' positions on abortion before election).

${ }^{248}$ Family Trust Found. of Ky. v. Wolnitzek, 345 F. Supp. 2d 672, 679 (E.D. Ky. 2004). One conservative organization, the Christian Coalition of Georgia, has generally framed the propositions on which candidates are asked to register their views in terms of positions opposed by the Coalition: "Secondary school-based clinics should dispense birth control devices without requiring prior parental notification and consent." Alyson M. Palmer, Christian Group's Judicial Survey Tackles Abortion, Taxes, Fulton COunTy DAily RePORT, July 28, 2006, available at http://www.law. $\mathrm{com} / \mathrm{jsp} /$ article.jsp?id=1153991136019 (last visited Dec. 31, 2007).

${ }^{249}$ See, e.g., Moerke, supra note 96, at 324 (describing questionnaire distributed by Austin Gay/Lesbian Political Caucus).

${ }^{250}$ See, e.g., Press Release, Florida Family Policy Council, Florida Family Policy Council Announces the Florida Judicial Accountability Project (July 24, 2006), avail- 
Another area in which loosened speech restraints serve conservative aims is criminal prosecution. While no political or judicial candidate would campaign on a platform of leniency toward criminals, ${ }^{251}$ a relatively tough "law and order" stance toward suspected and convicted criminals has long been associated with conservative philosophy. ${ }^{252}$ In some instances, a candidate's attempt to spell out this philosophy has provoked charges of exceeding limits on campaign expression. The White litigation itself was launched by a former candidate for the Minnesota Supreme Court who accused that court of untoward solicitude toward criminals. ${ }^{253}$ Nor was this an isolated instance; allegedly overzealous assurances that a candidate will crack down on criminals appear to be the chief source of disciplinary actions under campaign speech codes. ${ }^{254}$ In one of the few reported decisions since White to sustain sanctions, ${ }^{255}$ the Florida Supreme Court found a violation of state canons in a candidate's "cloaking her entire candidacy in the umbrella of law enforcement and portraying

able at http://www.christiannewswire.com/images/1153633747.pdf (announcing Florida Family Policy Council's 2006 Judicial Candidate Questionnaire for obtaining the "personal views of candidates on specific issues such as school vouchers, parental rights, abortion rights, assisted suicide, same sex marriage and criminal law"); Alyson M. Palmer, Christian Group's Judicial Survey Tackles Abortion, Taxes, Fulton CounTy DAILY REPORT, Jun. 28, 2006, available at http://www.law.com/jsp/article.jsp?id= 1153991136019 (questionnaire by Christian Coalition of Georgia's for judicial candidates asking agreement with, inter alia, propositions that "The Georgia Constitution does not recognize a right to abortion" and that "Griswold v. Connecticut, 381 U.S. 479 (1965) and Roe v. Wade, 410 U.S. 113 (1973) . . are examples of judicial activism”).

${ }^{251}$ See Anthony Champagne, Television Ads in Judicial Campaigns, 35 InD. L. Rev. $669,672 \mathrm{n} .21$ (2002) (finding that being "tough on crime" was a campaign theme in each of the four states studied); Failinger, supra note 21, at 462-63 (citing examples of campaign advertisements portraying advertiser as tough on crime); Hans A Linde, Elective Judges: Some Comparative Comments, 61 S. CAL. L. REv. 1995, 2000 (1988) (asserting that " $[\mathrm{e}]$ very judge's campaign slogan . . . is some variation of 'tough on crime'” ); see generally Weiss, supra note 191.

${ }^{252}$ See Barry C. Feld, The Transformation of the Juvenile Court-Part II: Race and the "Crack Down" on Youth Crime, 84 Minn. L. Rev. 327, 367 (1999); Ahmed A. White, Victims' Rights, Rule of Law, and the Threat to Liberal Jurisprudence, 87 Ky. L.J. 357, 390 (1999).

253 See White, 536 U.S. at 771.

${ }^{254}$ In re Haan, 676 N.E.2d 740, 741 (Ind. 1997) (finding violation of commit clause where campaign materials stated that candidate would "stop suspending sentences" and "stop putting criminals on probation"); In re Burick, 705 N.E.2d 422, 425, 427 (Ohio 1999) (ruling that pledge or promise and commit clauses were violated by, inter alia, advertisements stating that "Elizabeth Burick will be a tough Judge that supports the death penalty and isn't afraid to use it"); In re Kaiser, 759 P.2d 392, 396 (Wash. 1988) (campaign declarations that candidate would be tough on drunk driving held to violate pledges or promises clause).

${ }^{255}$ See supra Part II.C. 
herself as a future pro-prosecution/pro-law enforcement judge while characterizing her opponent as dismissing criminals and not holding them accountable." 256 (Notably, she had accused her opponent of "very definitely" being "a Liberal." ${ }^{257}$ ) Should the United States Supreme Court invalidate common versions of the pledges or promises and commit clauses, however, candidates will presumably be allowed to elaborate on their philosophy of law enforcement in this manner.

Finally, allowing judicial candidates to conduct themselves in the manner of traditional politicians could enhance the impact of business interests on judicial elections. For at least the past decade, various groups have expended considerable sums to promote candidates likely to rule favorably on issues affecting business. ${ }^{258}$ The Chamber of Commerce has been particularly active in seeking to prevent the election and especially reelection of judges thought excessively sympathetic to consumers and unions. ${ }^{259}$ Of course, restrictions on the speech of candidates have not prevented such groups from already exerting a substantial impact on judicial elections. Unshackling candidates from campaign restraints, however, would enable them to appeal more openly to supporters of a pro-business agenda. In this sense, the lifting of campaign speech limitations would indirectly magnify the role of wealth in elections, much as the abolition of limitations on campaign finance would do so directly. Conservatives on the Court have been outspoken in advocating the latter; ${ }^{260}$ it was not surprising in White to see them favor the former.

${ }^{256}$ In re Kinsey, 842 So. 2d 77, 82, 88-89 (Fla. 2003) (upholding judicial panel's finding).

257 Id. at 82.

258 John D. Echeverria, Changing the Rules by Changing the Players: The Environmental Issue in State Judicial Elections, 9 N.Y.U. ENVTL. L.J. 217, 225-37 (2001); Clive S. Thomas et al., Interest Groups and State Court Elections, 87 JUdiCATURE 135 (2003). Of course, instances of this phenomenon can be traced further back. See, e.g., John T. Wold \& John H. Culver, The Defeat of the California Justices: The Campaign, the Electorate, and the Issue of Judicial Accountability, 70 JUDICATURE 348, 350 (1987) (noting substantial contributions by oil and gas interests, agribusiness, auto dealers, and real estate interests to the 1978 campaign to oust Rose Bird from California Supreme Court).

259 See Carter, Boosting, supra note 92, at 29; John R. Wilke, Chamber of Commerce Targets State Races, WALl ST. J., Sept. 16, 2004, at A4.

260 See supra note 71. It has been widely speculated that Justice O'Connor's replacement by Justice Alito calls into jeopardy the Court's decision to sustain the McCain-Feingold federal campaign law in McConnell v. FEC, 540 U.S. 93 (2003). See, e.g., Robert Barnes \& Matthew Mosk, High Court to Revisit Campaign Finance Law: New Lineup on Bench Will Consider Ad Limits, WASH. POST, Jan. 20, 2007, at A1; Linda Greenhouse, Justices Revisit Campaign Finance Issue, N.Y. TIMES, Jan. 20, 2007, at A9. 
Nevertheless, in anticipating the fate of judicial campaign codes, it is fair to question whether the frequent alignment of untrammeled campaign speech with conservative values will influence the Court's rulings on restrictions. After all, ascertaining with certainty the motivation of even a single Justice is an impossible task, and Justices obviously conceive of themselves as detached from partisan influences. Whatever the motivation, a Justice's approach to an issue will not necessarily remain static. Moreover, which views qualify as conservative positions in law and politics, and the link between the two, is subject to debate. Finally, two members of the White majority have been replaced by Justices who have not weighed in on judicial campaign restraints, ${ }^{261}$ while more shifts in personnel may occur before the Court confronts the issue again. Thus, a forecast of doctrinal developments in this area cannot rest primarily on suspected preferences by members of the Court.

Even with these caveats, however, an attorney whose client had a stake in the strictness or leniency of campaign speech restraints would not ignore the potential impact of current Justices' personal predilections in this area. ${ }^{262}$ This is by no means a taboo subject. At least since the Court's decision in Bush v. Gore, ${ }^{263}$ observers have often ventured opinions on the role of Justices' political and policy preferences in their resolution of constitutional issues. ${ }^{264}$ One need not harbor a wholly cynical or deterministic outlook to discern certain

${ }^{261}$ Chief Justice Roberts and Justice Alito have taken the places of Chief Justice Rehnquist and Justice O'Connor.

${ }^{262}$ Cf. McCleskey v. Kemp, 481 U.S. 279, 321 (1987) (Brennan, J., dissenting) (inferring that lawyer's "candid reply" to inquiry by defendant in capital case would note that "there was a significant chance that race would play a prominent role in determining" defendant's sentence).

263531 U.S. 98 (2000).

264 Much of the outpouring of commentary on the decision speculated on whether the majority was motivated by partisan affinity in effectively resolving the disputed presidential contest between George W. Bush and Al Gore in favor of thenGovernor Bush. The accusatory nature of much of this literature is captured in the titles of books on the case, e.g., VinCENT Bugliosi, THE BETRAYAl OF AMERICA: How the Supreme Court Undermined the Consitution and Chose our President (2001); Alan M. Dershowitz, Supreme Injustice: How the High Court Hijacked ELECTION 2000 (2001), and articles in the press, e.g., Renata Adler, Irreparable Harm: The Unexpected Origins of the Supreme Court's Worst Decision, The New RePUBLIC, July 30, 2001; Hugo Young, Comment and Analysis: Democracy was Poisoned to Give Bush the Presidency, The GuARDian, Dec. 14, 2000, at 24. Analysis of the possible interplay of law and politics in the case, however, also appeared in serious legal journals. See, e.g., Jack M. Balkin, Bush v. Gore and the Boundary Between Law and Politics, 110 Yale L.J. 1407 (2001); Pamela S. Karlan, Unduly Partial: The Supreme Court and the Fourteenth Amendment in Bush v. Gore, 29 FLA. ST. U. L. REv. 587, 600-01 (2001). 
tendencies when conservative goals are implicated, or to conclude that attitudes toward judicial campaign speech are likely to follow that pattern. Nor should this inquiry be thwarted by complications in defining conservatism; whatever the simplification involved, journalists and legal commentators alike routinely distinguish "conservative" Justices from those deemed "liberal" or "moderate." 265

Two members of the Court universally described as conservative are Justices Scalia and Thomas. Professor Chemerinsky, for example, specifically pointed to them when he stated that conservative Justices have supplanted their liberal colleagues as premier defenders of First Amendment freedoms. ${ }^{266}$ In fact, however, Justices Scalia and Thomas have frequently sided with the state in resisting claims of expressive and associational rights supported by "liberal" colleagues like Justices Stevens and Souter. ${ }^{267}$ Rather than generally advocate expansive protection, they have selectively supported First Amendment claims in cases where the Court has been divided. Among the objects of their solicitude have been anti-abortion protesters; ${ }^{268}$ an organization seeking to exclude an "avowed homosexual" from membership; ${ }^{269}$ a

265 See, e.g., Mark Graber, Does it Really Matter? Conservative Courts in a Conservative Era, 75 FoRDHAM L. REV. 675 (2006); Robert Hume, The Use of Rhetorical Sources by the U.S. Supreme Court, 40 LaW \& SoC'Y REv. 817, 826-29; Michiko Kakutani, Court No Longer Divided: Conservatives in Triumph, N.Y. TIMES, Jan. 23, 2007, at E1; David Kirkpatrick, In Alito, G.O.P. Reaps Harvest Planted in '82, N.Y. TimES, Jan. 30, 2006, at A1.

266 Erwin Chemerinsky, Judicial Elections and the First Amendment, 38 TRIAL 78 (2002); see also Eugene Volokh, How the Justices Voted in Free Speech Cases, 1994-2000, 48 UCLA L. REv. 1191, 1198 (2001) (inferring from voting records that it would be wrong to "assume that the Left generally sides with speakers and the Right with the government").

${ }^{267}$ See, e.g., Garcetti v. Ceballos, 547 U.S. 410 (2006) (denying First Amendment protection to public employees disciplined for statements made pursuant to their official duties); United States v. Am. Library Ass'n, 539 U.S. 194 (2003) (sustaining facial validity of statute requiring public libraries to use Internet filters as condition for receipt of federal subsidies); Bartnicki v. Vopper, 532 U.S. 514 (2001) (recognizing First Amendment protection of media's disclosure of phone conversation that had been illegally taped by a third party); Legal Servs. Corp. v. Velazquez, 531 U.S. 533 (2001) (holding that law prohibiting Legal Services Corporation from funding legal representation involving efforts to amend or challenge welfare law violated First Amendment); Ark. Educ. Television Comm'n v. Forbes, 523 U.S. 666 (1998) (rejecting independent political candidate's challenge to exclusion from debate sponsored by state-owned television broadcaster); Timmons v. Twin Cities Area New Party, 520 U.S. 351 (1997) (finding that laws forbidding candidates to appear on ballot of more than one political party do not violate associational rights).

${ }^{268}$ See, e.g., Hill v. Colorado, 530 U.S. 703, 741-65 (2000) (Scalia, J., dissenting); Schenck v. Pro-Choice Network of W.N.Y., 519 U.S. 357, 385-95 (1997) (Scalia, J., concurring in part and dissenting in part).

${ }^{269}$ Boy Scouts of Am. v. Dale, 530 U.S. 640, 653-61 (2000). 
young man convicted of violating an ordinance banning fighting words that insult or provoke violence "on the basis of race, color, creed, religion or gender"; ${ }^{270}$ producers assessed the cost of generic advertising of California fruits; ${ }^{271}$ and opponents of limitations on political campaign contributions. ${ }^{272}$ Of course, it would be wrong to assume that First Amendment claimants who champion conservative social values, challenge "politically correct" laws, or represent moneyed interests automatically enlist the sympathy of Justices Scalia and Thomas-much less that their votes in these cases signal approval of the claimant's viewpoint. ${ }^{273}$ However, it would also be wrong to ascribe their votes to general enthusiasm for First Amendment rights, or to reject the possibility that substantive preferences have colored their approach to constitutional issues. In the realm of takings doctrine, their attachment to property rights has been a more reliable index of behavior ${ }^{274}$ than their ostensible commitment to federalism. ${ }^{275}$ Similarly, states may regard judicial campaign regulations as integral to judicial independence under their separation of powers, ${ }^{276}$ but in White Justices Scalia and Thomas were willing to overturn Minnesota's restriction. In this sense, White might be considered an illustration of what Richard Fallon described as the tendency of the conservative majority's substantive conservatism to trump its pro-

270 R.A.V. v. City of St. Paul, 505 U.S. 377 (1992).

271 Glickman v. Wileman Bros. \& Elliott, Inc., 521 U.S. 457, 504-06 (1997) (Thomas, J., joined by Scalia, J., dissenting).

${ }^{272}$ See e.g., McConnell v. FEC, 540 U.S. 93, 247-64 (2003) (opinion of Scalia, J.); Nixon v. Shrink Mo. Gov't PAC, 528 U.S. 377 (2000).

273 See, e.g., R.A.V., 505 U.S. at 396 (condemning petitioner's act of burning cross in black family's lawn as "reprehensible").

274 See, e.g., Kelo v. City of New London, 545 U.S. 469, 494-505 (2005) (O’Connor, J., joined by Scalia and Thomas, J.J., dissenting) (dissenting from holding that city could exercise eminent domain to acquire properties to transfer to corporation for development); Dolan v. City of Tigard, 512 U.S. 687 (1994) (O’Connor, J., concurring in part and concurring in the judgment) (joining Court's holding invalidating requirement that property owner grant easement as condition for receiving building permit); see also Roderick Hills, Jr., The Individual Right to Federalism in the Rehnquist Court, 74 GEO. WASH. L. REV. 888, 897 n.76 (2006).

${ }^{275}$ See Thomas Merrill, The Making of the Second Rehnquist Court: A Preliminary Analysis, 47 ST. Louis U. L.J. 569, 575 (2003); Betsy McCaughey Ross, New Support for States Rights: The Conflict Between Federalism and Equal Protection is the Defining Issue of Important Cases Now Before the Supreme Court, AM. OuTLOOK, Winter 2000, at 44-45 (listing Justices Scalia and Thomas as members of the "Federalist Five").

${ }_{276}$ See Republican Party of Minn. v. White, 416 F.3d 738, 773 (8th Cir. 2005) (Gibson, J., dissenting) (arguing that "[e]ven the narrowest notion of federalism" recognizes that the state has a compelling interest in separation of powers sufficient to justify partisan activities and solicitation clauses). 
federalism values. ${ }^{277}$ Given the disregard for the state's choice by Justices Scalia and Thomas, and the potential beneficiaries of lifting other restraints, a realist would expect similar treatment of these restraints.

A realist would also expect them to be joined by Chief Justice Roberts and Justice Alito in striking down campaign speech limitations. In light of these two Justices' brief tenure on the Court, a formalist might regard the extrapolation of their votes as crudely speculative. It is hardly far-fetched, however, to assume that these four Justices would be aligned in instances where a conservative position has been established. The president who appointed Chief Justice Roberts and Justice Alito had announced as a candidate that he would place on the Court Justices in the mold of Justices Scalia and Thomas. ${ }^{278}$ Scholarly commentators have openly cited the selection of these "two strongly conservative judges" ${ }^{279}$ as an example of "partisan entrenchment," ${ }^{280}$ i.e., appointing ideologically sympathetic Justices with a view toward "securing judicial allies who will work with and bolster one's existing political coalition." ${ }^{281}$ While it has often been said that presidents cannot foresee how their appointees' judicial philosophies will unfold, ${ }^{282}$ there is no reason to think that the two most recently appointed Justices will prove the disappointment to

277 Richard H. Fallon, Jr., The "Conservative” Paths of the Rehnquist Court's Federalism Decisions, 69 U. CHI. L. REV. 429, 434, 469 (2002). For his conception of substantive conservativism, Fallon adopts the classification method employed by Jeffrey Segal and Harold Spaeth in a number of studies. Id. at $447 \&$ nn.92-97. Under this scheme, conservative judicial positions include disfavoring the criminally accused and antagonism toward unions, injured plaintiffs, and government regulatory authority over businesses. Id. (citing Jeffrey A. Segal \& Albert D. Cover, Ideological Values and the Votes of U.S. Supreme Court Justices Revisited, 57 J. POL. 812, 815 \& n.4 (1989)); see also Erwin Chemerinsky, Progressive and Conservative Constitutionalism as the United States Enters the 21st Century, LAW \& ConTEMP. Probs., Summer 2004, at 53, 59 (arguing that Scalia and Thomas vote according to value choices and end-result conservatism).

278 Neil A. Lewis, The 2000 Campaign: The Judiciary; Presidential Candidates Differ Sharply on Judges They Would Appoint to Top Courts, N.Y. Times, Oct. 8, 2000, at 128.

${ }^{279}$ Jack M. Balkin \& Sanford Levinson, The Processes of Constitutional Change: From Partisan Entrenchment to the National Surveillance State, 75 FORDHAM L. REV. 489, 505 (2006).

280 Id.

281 Id. at 491; see also Jan Crawford Greenburg, Supreme Conflict: The Inside

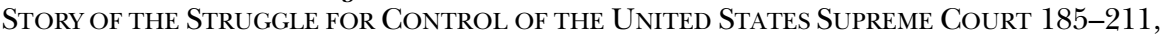
285-315 (2007) (providing accounts of the selections of Chief Justice Roberts and Justice Alito).

${ }^{282}$ See, e.g., Judgment on a Justice, Time, May 23, 1969, at 23-24 (quoting Alexander Bickel). 
President Bush that Chief Justice Warren and Justice Brennan are said to have been to President Eisenhower. ${ }^{283}$ Quite the opposite appears to be the case. As has been widely observed, Chief Justice Roberts and Justice Alito have thus far routinely voted with Justices Scalia and Thomas in cases where the Court is perceived to have split into conservative and liberal camps. ${ }^{284}$

As for Justice Kennedy, his anticipated opposition to additional campaign speech restrictions is both less explicable as conservative bias and more assured. Overall, Justice Kennedy has exhibited greater receptivity to First Amendment claims than Justices Scalia and Thomas, having parted company from these colleagues on a considerable number of occasions. ${ }^{285}$ It was no surprise, then, that in White Kennedy broadly objected to restraints on campaign speech. ${ }^{286}$ As Justice Stevens recognized in dissent, Justice Kennedy's position would logically preclude a pledges or promises clause like Minnesota's ${ }^{287}$-and doubtless most others.

\section{E. White and Other Camouflaged Watersheds}

The idea that White presages sweeping invalidation of judicial campaign speech restraints has ample parallels in other areas. Subject to the fact-driven nature of adjudication and other constraints on crafting opinions, the Court has often launched major doctrinal innovation in limited terms. These decisions have thus furnished critics a basis for resisting the wider implications of the holding. This is especially true in cases that offer relatively narrow grounds for resolution. Minnesota's version of the announce clause, for example, was the "broadest and most unreasonable" and had "long been aban-

${ }^{283}$ See Stephen J. Wermeil, The Nomination of Justice Brennan: Eisenhower's Mistake? A Look at the Historical Record, 11 CONST. COMMENT. 515, 534-36 (1995).

${ }^{284}$ See Thomas Goldstein, End of Term Statistics and Analysis, PrEvIEW U.S. SuP. CT. CASES, July 31, 2006, at 437-39; The Supreme Court-The Statistics, 120 HARV. L. REv. 372, 374-76 (2006).

${ }^{285}$ Compare Bartnicki v. Vopper, 532 U.S. 514, 528-35 (2001) (recognizing First Amendment protection of media's disclosure of phone conversation that had been illegally taped by a third party), with id. at 541-56 (Rehnquist, J., joined by Scalia and Thomas, JJ., dissenting); compare Legal Servs. Corp. v. Velazquez, 531 U.S. 533, 54649 (2001) (holding that law prohibiting Legal Services Corporation from funding legal representation involving efforts to amend or challenge welfare law violates First Amendment), with id. at 549-63 (Scalia, J., joined by Thomas, J., dissenting); compare Fla. Bar v. Went for It, Inc., 515 U.S. 618, 635 (1995) (upholding ban on personal injury lawyers' sending targeted direct-mail solicitations within thirty days of accident), with id. at 635-45 (Kennedy, J., dissenting).

${ }^{286}$ See 536 U.S. at 793 (Kennedy, J., concurring).

${ }^{287}$ Id. at 802 n.4 (Stevens, J., dissenting). 
doned by the ABA." 288 The Court therefore did not have to pronounce on the wider invalidity of campaign speech restrictions in order to strike down this especially vulnerable provision. Until future cases provide vehicles for taking this step, observers and bar associations can indulge in the possibility of White's modest reach. It appears, however, that they will find themselves in the position of predecessors who clung to similarly vain hopes.

A classic example of this phenomenon was the reaction by some observers to the Court's decision in NLRB v. Jones $\mathcal{E}$ Laughlin Steel Corp. $^{289}$ In retrospect, the holding marked the repudiation of constrictive interpretations of the Commerce Clause ${ }^{290}$ and the advent of enormous expansion of federal regulatory power. ${ }^{291}$ At the time, however, the decision was not generally understood as launching an era of near-plenary congressional authority under the Commerce Clause. As in White, the dispute offered circumstances that enabled the Court to resolve the case without committing itself to a more ambitious doctrine. Jones \& Laughlin Steel Corporation challenged Congress's ability to prohibit the dismissal of employees who attempt to organize a union. In sustaining the relevant provision of the National Labor Relations Act, the Court emphasized Congress's finding that interference with collective bargaining led to obstruction of commerce, ${ }^{292}$ the sprawling magnitude of Jones \& Laughlin's operations, ${ }^{293}$ and the "immediate and catastrophic" effect that disruption

288 Baran, supra note 34 , at 12.

289301 U.S. 1 (1937).

290 See, e.g., Carter v. Carter Coal Co., 298 U.S. 238, 303-04 (1936) (excluding conditions of employment of miners from Commerce Clause power); A.L.A. Schechter Poultry Corp. v. United States, 295 U.S. 495, 542-52 (1935) (holding that poultry shipped in interstate commerce is no longer subject to Commerce Clause power after reaching local slaughterhouse).

291 See, e.g., Katzenbach v. McClung, 379 U.S. 294, 301-02 (1964) (sustaining enforcement of civil rights statute against racial discrimination by local restaurant on ground that aggregate instances of discrimination have significant effect on interstate commerce); Wickard v. Filburn, 317 U.S. 111, 127-28 (1942); United States v. Darby, 312 U.S. 100, 117-24 (1941) (upholding imposition of minimum wage and maximum hour requirements for employees engaged in the production of goods for interstate commerce). For overviews of this development, see RONALD ROTUNDA \& John NowaK, Treatise on CONSTitutional LaW 446-56 (3d ed. 1999); Robert Stern, The Commerce Clause and the National Economy, 59 HARV. L. REv. 645, 645-93, 893-947 (1946). The Court ultimately began to impose limits on the reach of the Commerce Clause power, e.g., United States v. Morrison, 529 U.S. 598 (2000); United States v. Lopez, 514 U.S. 549 (1995), but this development did not negate the existence of the decades-long period of deference begun by Jones $\mathcal{E}$ Laughlin.

${ }^{292}$ Jones $\mathcal{F}^{2}$ Laughlin, 301 U.S. at 22 n.1, 31-32.

293 Id. at 25-27. 
of the company's activities would have on interstate commerce. ${ }^{294}$ The opinion did not disavow recent decisions invalidating comparably ambitious New Deal legislation, ${ }^{295}$ much less indicate that the power upheld would later encompass regulation of activities as remote from interstate commerce as service at a small local restaurant ${ }^{296}$ and loan-sharking. ${ }^{297}$ Understandably, many commentators appreciated the practical impact of Jones $\mathcal{E}$ Laughlin without recognizing that it heralded the collapse of meaningful limitations on Congress's Commerce Clause power. ${ }^{298}$ Still, a realistic appraisal of the likely course of the doctrine-including the effect of expected appointments by President Roosevelt-would have produced a more prescient grasp of the decision's pivotal significance.

A second development that may be instructive for the fate of limitations on judicial campaigning is the dismantling of officially sponsored racial segregation in the wake of Brown $v$. Board of Education. ${ }^{299}$ Brown is a landmark decision, but the ultimate general fall of state-mandated discrimination has tended to obscure the specific scope of Brown's holding. On its face, the decision addressed only whether "segregation of children in public schools solely on the basis of race" violates the Equal Protection Clause. ${ }^{300}$ Holding that it does, the Court found that forced separation generated in black schoolchildren "a feeling of inferiority as to their status in the community that may affect their hearts and minds in a way unlikely ever to be undone." ${ }^{301}$ This conclusion in turn rested largely on psychological and other studies cited by the Court. ${ }^{302}$ Neither the decision nor the terms in which it was explained necessitated the elimination of the broader regime of segregation. Yet, the Court soon issued a series of per curiam decisions finding violations of equality in the separation

294 Id. at 41.

295 See id. at 29-30, 40-41.

296 Katzenbach v. McClung, 379 U.S. 294, 298-305 (1964) (upholding ban on racial discrimination in places of public accommodation under Title II of the Civil Rights Act of 1964).

${ }^{297}$ Perez v. United States, 402 U.S. 146 (1971) (upholding federal criminal statute prohibiting individual instances of "extortionate credit transactions").

298 See, e.g., Haskell Donoho, Jurisdiction of the National Labor Relations Board-The Developing Concept of Interstate Commerce, 6 GEO. WASH. L. REV. 436, 450 (1937); Calvert Magruder, A Half Century of Legal Influence upon the Development of Collective Bargaining, 50 HARV. L. REV. 1071, 1095 (1937).

299347 U.S. 483 (1954).

300 Id. at 493.

301 Id. at 494

${ }^{302}$ See id. at 494 n.11. 
of parks, ${ }^{303}$ golf courses, ${ }^{304}$ and other public facilities. ${ }^{305}$ Only years later, in the course of invalidating a law barring white persons from marrying outside their race, did the Court promulgate a formal principle of strict scrutiny for racial classifications. ${ }^{306}$

While there is obviously no moral equivalence between those who urge restrictions on what judicial candidates may say and those who defended the vestiges of Jim Crow, these two sets of legal positions may well prove similarly untenable. The egregious inequality of dual school systems made them especially susceptible to legal challenge ${ }^{307}$ and thus a potent starting point for eradicating the regime of official racism. Similarly, Minnesota's dubious announce clause provided an attractive beginning for a project of eliminating judicial campaign speech restraints. Of course it remains to be seen whether the Roberts Court will object to campaign speech limits as thoroughly as the Warren Court opposed categorizing citizens by race. Again, however, there is little reason to think otherwise.

Finally, one further example illustrates in particular why proponents of campaign speech restrictions should take little comfort from the White Court's qualifications and disavowals. The advance in rights of reproductive and sexual autonomy that began in Griswold v. Connecticut $^{308}$ was by no means charted at the outset. Griswold struck down Connecticut's ban on the use of contraceptive devices as a violation of the right of privacy emanating from specific guarantees in the Bill of Rights. ${ }^{309}$ While referring to this right as comprising vague and potentially expansive "penumbras" formed by these guarantees, ${ }^{310}$ the Court's brief opinion repeatedly emphasized the law's specific invasion of the relation of "married persons."

${ }^{303}$ New Orleans City Park Improvement Ass'n v. Detiege, 358 U.S. 54 (1958) (per curiam), aff'g 252 F.2d 122 (5th Cir. 1958).

304 Holmes v. City of Atlanta, 350 U.S. 879 (1955) (per curiam), rev'g 223 F.2d 93 (5th Cir. 1955).

${ }^{305}$ Mayor \& City Council v. Dawson, 350 U.S. 877 (1955) (per curiam), aff' $g 220$ F.2d 386 (4th Cir. 1955) (public facilities included swimming pools, inter alia); see Herbert Wechsler, Toward Neutral Principles of Constitutional Law, 73 HARV. L. REv. 1, 22-23 (1959) (suggesting that the Court failed to articulate principled basis for extending Brown's ruling to such facilities).

${ }^{306}$ Loving v. Virginia, 388 U.S. 1, 11 (1967).

307 See generally RiCHARD KLUGER, SiMPLE JUSTICE (1975).

308381 U.S. 479 (1965).

309 . at $484-86$.

$310 \quad I d$. at 484 .

311 Id. at 480. The Court noted that the ban "operate[d] directly on an intimate relation of husband and wife." Id. at 482. The Court also stated that the law pursued its goals "by means having a maximum destructive impact" upon the marriage rela- 
later the Court invalidated a law barring unmarried persons from access to contraception on the ground that the right of privacy is "the right of the individual, married or single, to be free from unwarranted governmental intrusion into matters so fundamentally affecting a person as the decision whether to bear or beget a child." ${ }^{312}$ The next term, the Court's decision in Roe v. Wade ${ }^{313}$ added a woman's decision to terminate her pregnancy to the roster of privacy rights-a right not intimated in the Court's Griswold opinion. ${ }^{314}$ Nor did the Griswold Court contemplate the constitutional right to engage in homosexual conduct that was later recognized in Lawrence $v$. Texas $;{ }^{315}$ at least six of the participating Justices expressly or implicitly denied that the holding interfered with the state's ability to regulate this activity. ${ }^{316}$ Like White, Griswold thus involved a ready target-even the dissenters agreed that Connecticut had enacted "an uncommonly silly law" ${ }^{317}$ - whose toppling supplied a platform for inroads on other restrictions. The extension of White to invalidate most restraints on judicial campaign speech appears at least as logical as the outgrowth of autonomy rights from Griswold.

\section{THE DISPOSITION OF INDIVIDUAL RESTRICTIONS}

The general fate awaiting limitations on judicial campaign speech appears to be cast. The Court, however, has given no indication of announcing a principle of categorical invalidity. Instead, individual restrictions are more likely to arise in case-by-case litigation. Key aspects of the Court's reasoning in White, ${ }^{318}$ as well as successful

tionship, and noted that the prospect of police searching marital bedrooms for signs of violation was "repulsive to the notions of privacy surrounding the marriage relationship," and describing that relationship as "an association for as noble a purpose as any involved in our prior decisions. Id. at 485-86. Justice Goldberg, concurring, agreed that the law intruded upon "the right of marital privacy," see id. at 486, and Justice White, concurring in the judgment, stated that the case involved the right "to be free of regulation of the intimacies of the marriage relationship." Id. at 503.

${ }^{312}$ Eisenstadt v. Baird, 405 U.S. 438, 453 (1972).

313410 U.S. 113 (1973).

314 See John Hart Ely, The Wages of Crying Wolf: A Comment on Roe v. Wade, 82 YalE L.J. 920, 929 (1973).

539 U.S. 558 (2003).

316 See Griswold, 381 U.S. at 498-99 (Goldberg, J., concurring); id. at 500 (Harlan, J., concurring in judgment) (reaffirming his dissent in Poe v. Ullman, 367 U.S. 497, 552 (1961), which acknowledged the state's power to forbid homosexuality); $i d$. at 508-10 (Black, J., dissenting) (rejecting constitutional right of privacy).

Id. at 527 (Stewart, J., dissenting).

318 See supra Part II.B.2. 
challenges that have been mounted since that decision, ${ }^{319}$ suggest grounds for striking down these restraints. The core provisions of efforts to impede full-blown political campaigning by judicial candidates-the commit clause and pledges or promises clause-are especially susceptible to such rationales.

\section{A. Commit Clause}

States that retain a discrete commit clause typically prohibit "statements that commit or appear to commit the candidate with respect to cases, controversies or issues that are likely to come before the court." ${ }^{320}$ The restriction's fundamental rationale is that making commitments on legal issues "tends to undermine the fundamental fairness and impartiality of the legal system." ".21 While it may be "unlikely that the [White opinion] was intended to resolve the constitutionality of the Commit Clause," ${ }^{322}$ the Court's logic inescapably dooms that provision. In crucial respects, the commit clause is indistinguishable from Minnesota's announce clause. Moreover, a flaw that the White Court could have found but did not address-the announce clause's vagueness-can also be ascribed to the commit clause.

Attempts to defend the commit clause would probably emphasize the restriction's sharper focus and fit compared to the announce clause. Unlike the announcement of views, which connotes a range of inclinations on legal issues, the notion of commitment suggests statements of a firm and binding nature. More than announcements, commitments can be construed as candidates' "effectively telling the electorate: 'Vote for me because I believe X, and I will judge cases accordingly." " ${ }^{323}$ A commitment to rule in a certain manner may thus be said to negate openmindedness by predetermining the judge's position in a case irrespective of the merits. By the same token, commitments to act in a particular way as judge are more distinctly associated with active candidacies; arguably, therefore, the commit clause

\footnotetext{
319 See supra Part II.C.

320 See, e.g., Ark. Code of Judicial Conduct Canon 5(A) (3) (d) (ii) (2003); Me. COde OF Judicial Conduct Canon 5(B) (2) (2007).

${ }^{321}$ Ackerson v. Ky. Judicial Ret. \& Removal Comm’n, 776 F. Supp. 309, 315 (W.D. Ky. 1991).

${ }_{322}$ Briffault, supra note 94, at 215; see also GASs, supra note 119, at 14 (arguing that White "cannot reasonably be read as settling the question of the Commit Clause's constitutionality").

${ }^{323}$ Republican Party of Minn. v. White, 536 U.S. 765, 800 (2002) (Stevens, J., dissenting).
} 
does not suffer from the underinclusiveness that limited the announce clause's ban to campaigns.

Notwithstanding the surface plausibility of this line of reasoning, it will almost certainly fail in the face of White's overwhelming presumption against speech restrictions. Even assuming that judicial openmindedness is deemed a compelling interest, the Court's insistence on narrowly tailored measures leaves the commit clause subject to several attacks. First, the breadth of issues comprehended by the clause is the same as that which the Court viewed skeptically in White. According to the Court, confining the reach of the announce clause to issues likely to come before a court "is not much of a limitation at all;" after all, "“[t]here is almost no legal or political issue that is unlikely to come before a judge of an American court."” ${ }^{224}$ In addition, even a supporter of the commit clause has expressed concern that the inclusion of statements that "appear to commit" a candidate could render the commit clause problematically expansive. ${ }^{325}$ If that pitfall is somehow avoided, it is still unlikely that the commit clause's nexus with campaigns will extricate it from the underinclusiveness/overbreadth snare that White's logic appears to set. ${ }^{326}$ "Commitment" to a position may convey greater intensity than "announcement," but either can be issued outside the formal period of candidacy. Non-campaign forums identified by the Court as vehicles for announcements-books, speeches, or a judge's prior opinions $^{327}$-also lend themselves to expressions of commitment. ${ }^{328}$ Again, however, any cure for this underinclusiveness would inevitably offend the First Amendment. It would be impossible to craft a ban on commitments in these various forms without forbidding protected speech. In particular, the problem of retroactivity ${ }^{329}$ is aggravated in the case of commitments, for it is not clear what constitutes "commitment" to a position by someone who is not speaking in the capacity of a candidate.

In addition, the challenge of defining commitments outside of campaigns is only one part of a multifaceted problem of vagueness.

324 Id. at 772 (majority opinion) (quoting Buckley v. Illinois Judicial Inquiry Bd., 997 F. 2d 224, 229 (7th Cir. 1993)).

325 See Briffault, supra note 94, at 217.

326 See supra Part II.B.3.d.

327 See White, 536 U.S. at 779

328 See Juetten, supra note 87, at 697-98 (arguing that commit clause is similar to the invalid announce clause in that "it only applies to speech prohibition at certain times and in certain forms").

See supra notes 210-11 and accompanying text. 
Unless viewed formalistically, the very question of when a candidacy begins is potentially contentious, especially for sitting judges. ${ }^{330}$ Even in the context of unambiguous campaigning, moreover, the commit clause fails to give candidates definite guidance as to prohibited speech. Somewhat paradoxically, commitments seemingly comprise a smaller category than announcements ${ }^{331}$ but appear equally difficult to identify. Indeed, the blurry line between permissible announcements and forbidden commitments ${ }^{332}$ may elude candidates and enforcers alike. In In re Shanley, ${ }^{333}$ for example, the New York State Judicial Conduct Commission had determined that running as a "law and order candidate" breached the state's commit clause because the candidate at least appeared to commit herself to favoring the prosecution in criminal cases. ${ }^{334}$ The New York Court of Appeals, however, found that the phrase did not amount to a violation since it is "widely and indiscriminately used in everyday parlance and election campaigns." ${ }^{335}$ In contrast, the Kentucky Supreme Court ruled that a candidate whose advertisements described him as a candidate who was "pro-life" - undoubtedly another phrase "widely and indiscriminately used in everyday parlance and election campaigns""appeared to commit him to a position not only on abortion matters, but also on other controversies." 336

The imprecision of banning statements that signify commitment is compounded when extended to statements that "appear to commit" the candidate. The principal purpose of this phrase presumably is to capture expression that effectively communicates commitment without using that term explicitly. Even if the phrase is not inherently overbroad, candidates can reasonably argue that it will often be impossible to predict whether certain language will ultimately be

\footnotetext{
330 See McCarty, supra note 88 , at 71.

331 See Moerke, supra note 96, at 299 (stating that “'announce' . . means more than 'commit"').

${ }^{332}$ See Alexa Green, Comment, Judicial Election Candidates' Free Speech Rights After Republican Party of Minnesota v. White: Is the Problem Really Solved?, 44 SANTA Clara L. REv. 235, 265 (2003) (noting that many statements expressing a view can be subjectively understood to "appear to commit" a candidate).

333774 N.E.2d 735 (N.Y. 2002) (per curiam).

334 Id. at 736

335 Id. at 737.

336 Deters v. Ky. Judicial Ret. \& Removal Comm'n, 873 S.W.2d 200, 203 (Ky. 1994); see Briffault, supra note 94, at 203 (criticizing decision on ground that "a judge could consider himself pro-life as a matter of personal philosophy without feeling bound to reach a particular result in a case involving right-to-life issues if the evidence and the law pointed in the other direction").
} 
found to project an appearance of commitment. They will thus refrain from some protected speech because they feel compelled to "steer far wider of the unlawful zone." 337 In fact, perhaps mainly for this reason, a number of more recent versions of the commit clause have omitted this questionable phrase. ${ }^{338}$

Finally, even if the commit clause could be saved from vagueness and overbreadth through narrowing construction, ${ }^{339}$ the Court might still find this restriction intrinsically flawed. As noted earlier, ${ }^{340}$ the availability of recusal in principle makes the suppression of campaign speech unnecessary. Thus, on the one hand, a state might legitimately regard some statements as improperly committing a candidate with respect to a certain issue: that "victims have a right to expect judges to protect them by denying bond to potentially dangerous offenders[,]" ${ }^{341}$ or that the candidate "will be a tough Judge that supports the death penalty and isn't afraid to use it." ${ }^{342}$ The White Court's solicitude for speech, on the other hand, suggests that the proper remedy is petition by the bond applicant or capital defendant to seek replacement with a judge untainted by the bias revealed by campaign rhetoric.

Admittedly, the remedy of recusal is less attractive in the case of judges on a state's highest appellate court. Since a nonparticipating justice generally cannot be replaced, withdrawal simply shrinks the court rather than opening the door to a more dispassionate substitute. At the same time, however, White's logic suggests that states lack a compelling interest in precluding involvement at this level by judges who have displayed commitment to a legal position. In their nature, state supreme courts typically settle questions the resolution of which is open to reasonable competing interpretations. In their case, therefore, concerns that demonstrations of commitment will interfere with a justice's ability to "follow the law" have less relevance.

337 Speiser v. Randall, 357 U.S. 513, 526 (1958).

338 See, e.g., Cal. Code of Judicial Ethics Canon 5B \& Commentary (2006).

339 See Moerke, supra note 96, at 297-98.

340 See supra notes 188-98 and accompanying text.

${ }^{341}$ In re Kinsey, 842 So. 2d 77, 81 (Fla. 2003).

342 In re Burick, 705 N.E.2d 422, 425 (Ohio 1999). 


\section{B. Pledges or Promises Clause}

Much of whatever optimism remains about the viability of campaign speech regulation centers on the pledges or promises clause. ${ }^{343}$ A ban on "pledges or promises of conduct in office other than the faithful and impartial performance of the duties of the office" ${ }^{344}$ is widely thought to address a heightened threat to judicial impartiality. More than an announcement of views or even expression of "commitment" to a position, a " promise' to rule in a particular way strikes at the heart of a litigant's right to due process." ${ }^{345}$ The pledges or promises clause thus embodies the belief that "when preconceptions harden into prejudgments, the judicial function itself is subverted." ${ }^{346}$ The clause has also been defended as maintaining public confidence in the integrity of the judiciary; according to the Florida Supreme Court, a judicial candidate "should not be encouraged to believe that the candidate can be elected to office by promising to act in a partisan manner by favoring a discrete group or class of citizens." ${ }^{347}$ Moreover, the inherent scope of the pledges or promises clause appears to exempt it from charges of underinclusiveness; presumably only candidates can make meaningful pledges or promises. ${ }^{348}$ These arguments gain further support from judicially drawn distinctions between the announce clause and bans on campaign promises. The Seventh Circuit, for example, while anticipating White in striking down Illinois's announce clause, affirmed the state's power to forbid "promises to rule in particular ways in particular cases or types of cases." ${ }^{349}$ White itself took pains to distinguish statements prohibited by Minnesota's invalid announce clause from "campaign promises." 350

Still, however appealing these considerations as policy, the pledges or promises clause is likely to run afoul of the Court's fundamental aversion to campaign speech restrictions. As discussed earlier, ${ }^{351}$ the greater threat to openmindedness that campaign promises

343 See, e.g., Moerke, supra note 96, at 310 (describing future of clause as "fairly bright").

344 Model Code of Judicial Conduct Canon 5A (3) (d) (ii) (1990) (amended 2003).

Recent Changes, supra note 125, at 835 (transcript remark of Eric P. Schroeder).

346 Briffault, supra note 94, at 211.

347 In re Kinsey, 842 So. $2 \mathrm{~d}$ at 87.

348 See Young, supra note 96, at 457 (stating that pledges and promises "are unlikely to be made outside the context of a campaign").

${ }^{349}$ Buckley v. Ill. Judicial Inquiry Bd., 997 F.2d 224, 230 (7th Cir. 1993).

350536 U.S. at 780.

351 See supra notes 207-13 and accompanying text. 
may pose compared to nonpromissory statements does not immunize the pledges or promises clause from underinclusiveness. Indeed, the Court's description of campaign promises as "the least binding form of human commitment" ${ }^{\text {"52 }}$ suggests that their danger to openmindedness is only relative, and perhaps not grave at all. At the same time, the standard version of the pledges or promises clause is also likely to founder on the overbreadth doctrine. It is not difficult to conjure up legitimately promised conduct outside the bland and generic category of "the faithful and impartial performance of the duties of the office." A candidate could, for example, promise to "respect the First Amendment rights of protesters" or (perhaps more realistically) to "enforce our criminal laws as they are written." ${ }^{353}$ Thus, almost a decade before White, Judge Posner denigrated the pledges or promises clause as dealing with the problem that it addressed "in the most comprehensive way possible." ${ }^{354}$ Likewise, a number of courts since White have struck down the pledges or promises clause on overbreadth grounds. ${ }^{355}$

The 2007 ABA Model Code tacitly deals with overbreadth by specifying prohibited rather than permissible pledges and promises. Under the new Code, a candidate for judicial office "shall not, with respect to cases, controversies, or issues that are likely to come before the court, make pledges, promises, or commitments that are inconsistent with the impartial performance of the adjudicative duties of the office." ${ }^{, 56}$ This ban is certainly more narrowly tailored to promoting openmindedness and its appearance than the version that has met with recent hostility in the courts. However, it retains the problem of identifying proscribed statements with sufficient clarity to escape the vice of vagueness. This difficulty stems largely from a dilemma inherent in any attempt to regulate this category of expression. On the one hand, the reach of a meaningful pledges or promises clause cannot be confined to campaign statements that literally include one of these terms; otherwise, candidates "will simply formulate all their

352 Republican Party of Minn. v. White, 536 U.S. 765, 780 (2002).

353 See Buckley, 997 F.2d at 228 (7th Cir. 1993) (stating that clause would not allow a candidate to "pledge himself to be a strict constructionist ... . [or] a legal realist").

${ }^{354} I d$.

355 See, e.g., Kan. Judicial Watch v. Stout, 440 F. Supp. 2d 1209, 1227-28, 1231-34 (D. Kan. 2006); N.D. Family Alliance, Inc. v. Bader, 361 F. Supp. 2d 1021, 1039 (D.N.D. 2005); Family Trust Found. of Ky. v. Wolnitzek, 345 F. Supp. 2d 672, 701 (E.D. Ky. 2004).

356 Model Code of Judicial Conduct R. 4.1(A) (13) (2007). 
campaign pledges in non-promissory language." 357 White's invalidation of the announce clause makes the ability to sanction de facto promises especially vital to effective enforcement. ${ }^{358}$ On the other hand, however, the same blurry line between disguised promises and less binding expression that challenges regulators may also baffle candidates. For example, a judge was admonished by the Texas Commission on Judicial Conduct for stating in his campaign literature: "I'm very tough on crimes where there are victims who have been physically harmed . . . . I have no feelings for the criminal." ${ }^{359}$ According to the Commission, these statements amounted to a pledge "not to show leniency toward violent criminals." Similarly, the ABA has opined that a judge's reelection slogan of "A strict sentencing philosophy! A hard working man!" can be regarded by voters as a pledge of future judicial conduct. ${ }^{361}$ These and other ${ }^{362}$ determinations of implied promises are hardly self-evident, and the chilling effect on candidates unable to anticipate the judgments of disciplinary bodies may ultimately prove intolerable to the Court. ${ }^{363}$

Besides uncertainty as to what counts as promises, the ABA's pledges or promises clause also invites a separate charge of vagueness. Even somehow devising means for alerting candidates to the classification of their intended statements as promises would still leave candidates hazy on a key point. The ban on promises "that are

357 Raban, supra note 52, at 218; see Morrison, supra note 54, at 726 (arguing that if statements that come "close to prejudgment" are not prohibited, "then there is no point in having a no pledge rule"); see also William Glaberson, Fierce Campaigns Signal a New Era for State Courts, N.Y. TIMES, June 5, 2000, at A1.

358 See Republican Party of Minn. v. White, 536 U.S. 765, 819 (2002) (Ginsburg, J., dissenting) (arguing that " $[\mathrm{u}]$ ncoupled from the Announce Clause, the ban on pledges or promises is easily circumvented"); Bogard, supra note 91, at 17 (asserting that because of White, candidates "will not have to be particularly inventive to find ways around the pledge clause").

359 Baran, supra note 34, at 13 (citing Bruce Hight, Judge Violated Conduct Code, Panel Decides, Austin-American Statesman, Jan. 31, 2001).

360 Id.

361 ABA Comm. on Ethics and Prof'l Responsibility, Informal Op. 1444 (1980).

${ }^{362}$ See, e.g., Summe v. Judicial Ret. and Removal Comm'n, 947 S.W.2d 42, 47 (Ky. 1997) (judge's advertisement urging election of judge who "will let no one walk away" deemed improper promise "in context of" judge's campaign); In re Birnbaum, 1997 WL 640687 (N.Y. Com. Jud. Cond. Sept. 29, 1997) (finding violation of pledges or promises clause by judge who emphasized in his campaign that he was a tenant and his opponent was a landlord, and that tenants had applauded his performance as a housing judge).

363 See Baran, supra note 34, at 12 n.4 (comparing "in terrorem effect of broad or ambiguous interpretations" of announce clause with deterrence of speech induced by uncertain reach of pledges or promises clause). 
inconsistent with the impartial performance of the adjudicative duties of the office" may avoid overbreadth, ${ }^{364}$ but at the cost of reducing the guidance afforded by the typical state version. If promises can be reliably identified, then states' limited imprimatur for promises of "the faithful and impartial performance of the duties of the office" provides a small but relatively clear safe harbor. In contrast, the ABA provision resembles Laurence Tribe's hypothetical example of a "sharply focused" but "patently vague" statute: "It shall be a crime to say anything in public unless the speech is protected by the first and fourteenth amendments." 365 While the model pledges or promises clause is less extreme than this, it is similarly open to attack as giving insufficient notice of proscribed expression. Obviously drawing from White, the Model Code defines impartiality as "the condition of being without bias or prejudice in favor of, or against, particular parties or classes of parties, or their representatives, and maintenance of an open mind in considering issues that may come before a judge." 366 It is doubtful, however, that a state could fully catalogue the range of promises that would breach impartiality in one of these senses. In the absence of such comprehensive direction to candidates, the Court would probably conclude that the model restriction's vagueness excessively stifles protected campaign speech.

To defenders of the pledges or promises clause, this analysis suggests the disheartening conclusion that the doctrines of underinclusivness, overbreadth, and vagueness preclude states from crafting effective regulation of candidates' promises. While this is probably true, the futility of the clause might be explained on simpler grounds: viz., other than promissory agreements to commit illicit acts, ${ }^{367}$ the category of proscribable promises does not exist. Campaign promises may be generally immune from prohibition for two reasons. First, as with announcements of views and expressions of commitment, recusal of judges whose promises have displayed excessive bias provides a less restrictive alternative to suppressing speech. Granted, broad license to issue campaign promises combined with rigorous recusal standards could produce unworkably rampant disqualification of judges. Fear of this specter, however, would not justify prohibiting promises; under strict scrutiny, the government bears the burden of

364 But see supra notes 207-13 and accompanying text.

365 Laurence H. Tribe, American Constitutional LaW 1031 (2d ed. 1988).

366 Model Code of Judicial Conduct Terminology (2007).

${ }^{367}$ See supra notes 166-68 and accompanying text. 
demonstrating that less speech-intrusive measures cannot accomplish the government's objectives. ${ }^{368}$

The second reason for protecting judicial campaign promises relates to the objection that the ready availability of recusal would render campaign promises self-nullifying. That is, it has been suggested that a liberal recusal policy would "constitute electoral fraud" because judicial candidates would knowingly "induce[]" the public to elect them on the basis of promises that they could not fulfill. ${ }^{369}$ Strict scrutiny of speech restrictions, however, is designed to maximize free expression, not the ability of speakers to carry out their agendas. If a particular promise in fact betrays an inability to judge impartially when the issue in question arises, then the promisor is not entitled to participate in the decision; a constitutional right to express bias does not imply a right to implement it. Conversely, acceptance of the argument against expansive recusal would not save the pledges or promises clause, for the argument assumes the right of candidates to make promises to be kept. Rather, a determination that most campaign promises could not constitute grounds for disqualification would entail rejection of a proposition that the Court declined to address in White: that judicial openmindedness constitutes a compelling interest. This possibility is hardly far-fetched; indeed, the premise that openmindedness is an interest sufficiently weighty to justify squelching political speech is arguably in tension with other aspects of the opinion. If it is affirmatively "desirable" to have judicial candidates who harbor preconceptions on legal issues, ${ }^{370}$ and imperative that they be allowed to share these views with the electorate, it is doubtful that the state can forbid candidates to in effect express their belief that some preconceptions are firmly settled. A candidate who is resolutely wed to a certain outcome will vote that way as judge in any event; the question is whether voters may be told in advance. Under this view, a party who believes that a judge has improperly adhered to a campaign promise should challenge the pertinent ruling rather than the bias that allegedly gave rise to it.

The implications of minimal restraints on campaign promises are admittedly troubling, but not unthinkable. With or without expansive recusal, a broad right to issue promises would permit flagrant assurances by judicial candidates. A candidate might promise, for example, "never to go easy on" accused car thieves or always to "look fa-

368 ACLU v. Reno, 521 U.S. 844, 874 (1977).

369 Shepard, supra note 7, at 1082-83.

${ }^{370}$ Republican Party of Minn. v. White, 536 U.S. 765, 778 (2002). 
vorably on" plaintiffs in suits against insurance companies. Similar latitude, however, is already available to candidates for legislative or executive office. In principle, a candidate for governor could promise with legal impunity to spend recklessly, ignore irksome environmental regulations, and deal harshly with minorities. Obviously, successful candidates do not make these kinds of promises (although arguably some have carried out such policies); we rely, however, on electoral pressures rather than legal safeguards to deter such guarantees. Aspiring legislators and executives of course still sometimes make irresponsible promises-hence the White Court's dismissive view of promises' binding force-but again we depend on open debate and voters' reactions to cope with this tendency. Advocates of the pledges or promises clause argue that the fundamental difference between the judiciary and other branches of government make such analogies inappropriate. In White, that rationale proved insufficient to sustain the announce clause against the principle that government could not "prohibit candidates from communicating relevant information to voters during an election." extension of this logic if the Court decided that promises, too, convey "relevant information" that voters are entitled to hear.

\section{Misrepresent Clause}

The ABA Model Code's newest misrepresent clause provides that candidates for judicial office shall not "knowingly, or with reckless disregard for the truth, make any false or misleading statement." 372 The 1990 Model Code more specifically forbade candidates to "knowingly misrepresent the identity, qualifications, present position or other fact concerning the candidate or an opponent." ${ }^{373}$ That provision in turn had revised the 1972 Code, which prohibited a candidate from "misrepresent[ing] his identity, qualifications, present position, or other fact." 374 The 1990 misrepresent clause was obviously designed to supply the absence of an intent requirement in the prior version, and many states by either explicit language ${ }^{375}$ or judicial construction $^{376}$ have adopted a clause targeting only knowing or reckless

\footnotetext{
$371 \quad I d$. at 782.

372 Model Code of Judicial Conduct R. 4.1(A) (11) (2007). 2003)

Model Code of Judicial Conduct Canon 5A(3)(d) (iii) (1990) (amended

374 Model Code of Judicial Conduct Canon 7B(1) (c) (1990).

375 See, e.g., Ga. Code of Judicial Conduct, Canon 7B(1) (c) (2006).

376 See, e.g., Butler v. Ala. Judicial Inquiry Comm'n, 802 So. 2d 207, 217-18 (Ala. 2001); In re Chmura, 608 N.W. 2d 31, 42-43 (Mich. 2000).
} 
misrepresentations. Although prospects for the misrepresent clause have been rated by one thoughtful commentator as exceptionally bright, ${ }^{377}$ none of these variations appears likely to pass constitutional muster under the post-White regime.

First, assuming a degree of state power to curb judicial candidates' misrepresentations, the ABA's repeated revisions illustrate the difficulty of designing a ban that avoids First Amendment pitfalls. The 1990 Code's prohibition on misstating the "identity, qualifications, present position or other fact concerning the candidate or an opponent" appears to sweep in enough protected speech to raise serious overbreadth concerns. The 2007 version, in categorically forbidding "false or misleading statement[s]," encompasses even more speech. Both provisions also invite charges of vagueness. What constitutes misrepresentation of a candidate's "present position," for example, can be hopelessly subjective. Likewise, while barring "misleading" speech may be integral to proper regulation of securities transactions ${ }^{378}$ and commercial advertising, ${ }^{379}$ holding political candidates to account for misleading statements in a realm where discussion "should be uninhibited, robust, and wide-open" 380 is problematic in the extreme.

More importantly, the misrepresent clause-perhaps even more than the pledges or promises clause-is hampered less by deficiencies in craftsmanship than by fundamental resistance to regulating political candidates' speech. All forms of the clause hinge on the premise that judicial campaigns involve a unique constellation of interests; comparable restrictions on candidates for legislative and executive office would almost certainly violate the First Amendment. Brown $v$. Hartlage, ${ }^{381}$ discussed earlier in connection with candidates' promises, ${ }^{382}$ also sheds light on states' severely limited power to restrict false campaign speech. Brown's election to a county commission had been nullified because of his pledge-later retracted-to lower commissioners' salaries if elected. The implicit representation that

\footnotetext{
377 See Moerke, supra note 96, at 312; see also Friedland, supra note 97, at 605 n.192 (suggesting that state provisions patterned on 1990 Model Code's misrepresent clause are constitutional).

378 See Everest Securities, Inc. v. SEC, 116 F.3d 1235, 1237, 1240 (8th Cir. 1997); SEC v. Burns, 816 F.2d 471, 473 (9th Cir. 1987).

379 See Cent. Hudson Gas \& Elec. Corp. v. Pub. Serv. Comm'n, 447 U.S. 577, 566 (1980).

380 N.Y. Times v. Sullivan, 376 U.S. 254, 270 (1964).

381456 U.S. 45 (1982).

382 See supra notes 165-71 and accompanying text.
} 
Brown could do so was apparently false because state law barred commissioners from reducing their salaries while in office. ${ }^{383}$ In reinstating the election of Brown, who had initially been unaware of this constraint, the Court declared that " $[\mathrm{t}]$ he chilling effect of such absolute accountability for factual misstatements in the course of political debate is incompatible with the atmosphere of free discussion contemplated by the First Amendment in the context of political campaigns." ${ }^{384}$ This conclusion carries overtones of the Court's pronouncement in Cantwell v. Connecticut ${ }^{355}$ that the Constitution's command of unimpeded political discourse precludes the state from barring "resort[] to exaggeration, to vilification of men who have been, or are, prominent in church and state, and even to false statement." ${ }^{386}$ Even an observer who believes that the Court's campaign finance jurisprudence provides some support for restricting false campaign speech $^{387}$ acknowledges that such restrictions are in tension with the central place of political expression under the First Amendment. ${ }^{388}$ While a number of states have "statutes prohibiting false political speech regarding political candidates," these do not appear to authorize disqualification or other official penalties against candidates for campaign misrepresentations. ${ }^{389}$ Imposition of such sanctions, or of prior restraints, would almost certainly fail in light of the principle that in the realm of public debate, "every person must be his own watchman for truth, because the forefathers did not trust any government to separate the true from the false for us." ${ }^{390}$ This country's long history of campaign distortions and scurrilous attacks ${ }^{391}$ un-

383 Brown, 456 U.S. at 50.

384 Id. at 61 .

385310 U.S. 296 (1940).

${ }^{386} I d$. at 310 .

387 See William P. Marshall, False Campaign Speech and the First Amendment, 153 U. PA. L. Rev. 285, 300-22 (2004).

388 See id. at 298 \& n.57 (quoting Mills v. Alabama, 384 U.S. 214, 218 (1966) (" $[\mathrm{T}]$ here is practically universal agreement that a major purpose of [the First] Amendment was to protect the free discussion of governmental affairs.") (internal quotation marks omitted)).

${ }^{389}$ See Becky Kruse, Comment, The Truth in Masquerade: Regulating False Ballot Proposition Ads Through State Anti-False Speech Statutes, 89 CAL L. REV. 129, 132 \& n.13 (2001) (collecting statutes).

390 Thomas v. Collins, 323 U.S. 516, 545 (1945) (Jackson, J., concurring) (emphasis added), quoted in State ex rel. Pub. Disclosure Comm'n v. 119 Vote No! Comm., 957 P.2d 691, 695 (Wash. 1998).

${ }_{391}$ See generally Kerwin C. Swint, Mudslingers: The Top 25 Negative Political CAMPAigns OF All Time (2006). 
derscores our system's reliance on counterspeech rather than regulation to correct candidates' misrepresentations.

It is true, as the Brown Court acknowledged, that libel law demonstrates the lesser protection accorded falsehoods under the First Amendment, ${ }^{392}$ and some commentators have suggested that defamation doctrine supports the misrepresent clause. ${ }^{393}$ Defamation suits, however, involve a different calculus of interests from attempts to restrain political candidates from issuing falsehoods. While provision of redress for libel and slander qualifies as state action, ${ }^{394}$ recovery of damages for defamation remains essentially a private action in tort. ${ }^{395}$ A suit to vindicate an individual's "interests in reputation and good name" ${ }^{396}$ is thus a far cry from either the state's imposition of a prior restraint on core political speech in the heat of a campaign or the overturning of the result of an election on the basis of such speech. Concerns of manageability alone-expeditiously determining falsehood for injunctive relief, fixing the causal connection between a candidate's misrepresentation and electoral victory post hoc-suggest the futility of seeking to regulate campaigns in this manner.

In the aftermath of White, there is no compelling reason to think that these obstacles to regulation of false campaign speech apply with appreciably less force to judicial races. That decision established the Court's refusal to relent in its normal scrutiny of restraints on candidates' speech in the case of judicial elections; there do not appear to be any unique justifications for the misrepresent clause that would allow it to survive this scrutiny. An early opponent of judicial campaign speech restrictions explained why candidates for all offices are permitted to abuse their freedom of speech:

Speakers may distort the truth, calumniate innocent opponents, or misrepresent their own achievements. The right to speak freely protects a process that allows for response by opponents, reflection by critics, and assessment by listeners. . . . Any political candidate may lie or pander to the popular will to get votes. Despite this risk, the framers of the first amendment preferred the

392456 U.S. 45, 60 (1982); see Gertz v. Robert Welch, Inc., 418 U.S. 323, 340 (1974) (stating that "there is no constitutional value in false statements of fact").

393 See, e.g., Briffault, supra note 94, at 221-22; Moerke, supra note 96, at 311-12; see also Chemerinsky, Restrictions, supra note 9, at 746 (citing defamation law to refute proposition that "there are no limits on what judges can say in election campaigns").

394 N.Y. Times v. Sullivan, 376 U.S. 254, 265 (1964).

395 See Dan B. Dobbs, The LAW OF TORTS $\$ 400$ (2000).

396 William Prosser, HaNdBook OF THE LAW OF TorTs 737 (4th ed. 1971). 
open and full discussion of views, complete with full and open rebuttal, to suppression of speech. ${ }^{397}$

Still, in a typical defense, Georgia argued that its version of the clause served the compelling interests of "preserving the integrity, impartiality, and independence of the judiciary" and "ensuring the integrity of the electoral process and protecting voters from confusion and undue influence." ${ }^{398}$ However powerful these goals, they do not furnish reason to restrict dishonesty by judicial candidates more than that of candidates for other offices. Of the roster of interests that Georgia invoked, only impartiality is exceptionally prized in judges. ${ }^{399}$ Yet, as White defined that interest, it is unlikely that a ban on campaign misrepresentations would be deemed narrowly tailored to averting bias toward parties or preserving openmindedness. The Eleventh Circuit's conclusion that Georgia's provision failed strict scrutiny ${ }^{400}$ was therefore wholly to be expected.

\section{Political Activity Clauses}

Like its predecessors, the 2007 ABA Model Code contains several provisions forbidding judicial candidates to engage in a variety of political activities. These include holding office in a political organization, making speeches on behalf of a political organization, publicly endorsing or opposing candidates for public office, or using a political party's endorsement. ${ }^{401}$ Many states have adopted similar restrictions on candidates' political conduct. ${ }^{402}$

On the surface, these provisions arguably stand on a stronger footing than prohibitions of candidates' commitments, promises, and misrepresentations. While those clauses invade judicial candidates'

397 Snyder, supra note 48, at 217, 249 (emphasis added).

398 Weaver v. Bonner, 309 F.3d 1312, 1319 (11th Cir. 2002) (internal quotation marks omitted).

399 See Briffault, supra note 94, at 220 (questioning whether interest in integrity uniquely applies to the judiciary and "whether the integrity of the judiciary is more threatened by candidate misrepresentations than the integrity of elected executives and legislators"). But see id. at 222 (indicating that the misrepresent clause could be supported by a compelling interest in "informed voter decision making" in all elections).

Weaver, 309 F.3d at 1319-22.

401 Model Code of Judicial Conduct R. 4.1(A) (1)-(3), (7) (2007).

402 See, e.g., Fla. Code Of Judicial Conduct Canon 7 A(1) (b) (2006) (forbidding candidate to "publicly endorse or publicly oppose another candidate for public office”); GA. CODE OF JUDICIAL CONDUCT Canon 7 A(1) (2006) (barring candidate from office in a political organization); PA. CODE OF JUdicial Conduct Canon 7 A(1) (b) (2006) (prohibition on speeches for a political organization or candidate); S.D. CODIFIED LAWS $\$ 12-9-2$ (prohibiting political party's endorsement of candidate). 
core campaign expression, restraints on political participation do not work a direct interference with candidates' ability to present their views and intentions. Moreover, the idea that insulating judges from partisan politics promotes a compelling interest in judicial independence is rooted in the fundamental principle of separation of powers. ${ }^{403}$ Defenders of limits on political participation can assert the danger posed by judicial candidates' "placing themselves in debt to powerful and wide-reaching political organizations that can make or break them in each election." 404 They can also point to the Court's recognition elsewhere that the threat of government's politicization can sometimes justify curbing what is otherwise protected political activity. ${ }^{405}$ Against the backdrop of these principles, courts before White not infrequently disciplined judges for partisan behavior. ${ }^{406}$

Nonetheless, most restrictions on partisan activities are likely to suffer the same fate as the announce clause in White. Indeed, the logic of rejecting the announce clause can be readily extended to restraints on political participation. White's holding rests on a belief that a judicial candidate's espousal of views does not inherently betray a lack of impartiality. In a sense, involvement in political affairs represents affirmation of those views. From the voter's perspective, a candidate's partisan activity may communicate the candidate's depth of commitment to certain values and principles more clearly and convincingly than mere campaign rhetoric. Political participation thus serves an efficient signaling function for the electorate. As to preserving openmindedness, a ban on partisan activities during a campaign falls prey to the underinclusiveness that defeated the announce clause and threatens all restrictions on judicial campaign

${ }^{403}$ See Maderal, supra note 96, at 819; Weiser, supra note 96, at 665-701; see also Clements v. Fashing, 457 U.S. 957, 967-73 (1982) (upholding law requiring resignation of judges who run for legislative office).

${ }^{404}$ Republican Party of Minn. v. White, 416 F.3d 738, 768 (8th Cir. 2005) (Gibson, J., dissenting); see also Briffault, supra note 94, at 232 (stating that "[j] udges who are politically active within their parties can come under pressure to conform their judicial decisions to the party line").

${ }^{405}$ See, e.g., McConnell v. FEC, 540 U.S. 93, 142-61 (2003) (upholding limits on contributions to political candidates); U.S. Civil Serv. Comm'n v. Nat'l Ass'n of Letter Carriers, 413 U.S. 548, 564-65 (1973) (sustaining ban on federal employees' political activities on the rationale that prohibition "will reduce the hazards to fair and effective government").

${ }^{406}$ See, e.g., In re Barrett, 593 A.2d 529 (Del. 1991) (attending political fundraisers); In re Glickstein, 620 So. 2d 1000 (Fla. 1993) (writing letter to editor endorsing another judicial candidate); In re Turner, 573 So. 2d 1 (Fla. 1990) (assisting son's campaign efforts); In re Codispoti, 438 S.E.2d 549 (W. Va. 1993) (assisting wife's campaign for office). 
speech. In the Eighth Circuit's acerbic words on remand in White, " $[t]$ he few months a candidate is ostensibly purged of his association with a political party can hardly be expected to suddenly open the mind of a candidate who has engaged in years of prior political activity." ${ }^{\prime 07}$ By the same token, political activity clauses are an example par excellence of the underinclusiveness/overbreadth bind latent in the White Court's analysis. Curing underinclusiveness by disqualifying any candidate who had engaged in the provisions' prohibited activities outside the campaign would be manifestly illegitimate. Furthermore, restrictions on political activity emphatically illustrate resort to recusal as a means to avoid impinging on speech and conduct ordinarily protected by the First Amendment. The range of issues in which candidates' partisan affiliation is deemed to compromise their openmindedness will probably be considered relatively narrow. Accordingly, recusal in those instances when such issues arise offers a manageable alternative to precluding significant political involvement altogether. ${ }^{408}$

Notwithstanding at least one court's continued enforcement of political activity clauses, recognition of their tenuous status appears to be gaining. In In re Raab, ${ }^{409}$ the New York Court of Appeals sustained the state's limitations on judicial candidates' partisan involvement. The Court determined that these restrictions served the State's "overriding interest in the integrity and impartiality of the judiciary" by guarding against judges' "actually or appear[ing] to make the dispensation of justice turn on political concerns." ${ }^{410}$ Rejecting an allegation of underinclusiveness, the Court reasoned that the rules were tailored to "limiting the degree of involvement of judicial candidates in political activities during the critical time frame when the public's attention is focused on their activities." ${ }^{111}$ As noted earlier, however, state supreme courts' investment in their own rules of candidate conduct make them questionable arbiters of campaign speech restrictions. $^{412}$ More telling in all likelihood is the Eighth Circuit's thoroughgoing dismissal of the rationales advanced for Minnesota's

${ }^{407}$ White, 416 F.3d at 758 (invalidating Minnesota's partisan activities clause).

${ }^{408}$ See Spargo v. N.Y. State Comm'n on Judicial Conduct, 244 F. Supp. 2d 72, 8889 (N.D.N.Y. 2003), rev'd on other grounds, 351 F.3d 65 (2d Cir. 2003), cert. denied, 541 U.S. 1085 (2004) (describing recusal as "proper consequence" of judge's politicallybased bias).

409793 N.E.2d 1287 (N.Y. 2003) (per curiam).

${ }^{410} I d$. at 1291 (citations and internal quotation marks omitted).

${ }^{411} I d$. at 1293.

412 See supra notes 225-29 and accompanying text. 
partisan activities clause. ${ }^{413}$ That decision reinforces the expectation that the Supreme Court's decision in White "will increase the influence of political parties in judicial elections." ${ }^{414}$ Nor has the Eighth Circuit been alone in recognizing the apparent implications of White for restrictions on political behavior; soon after the Court's decision, the North Carolina Supreme Court drastically relaxed its prohibition on partisan activity. ${ }^{415}$

\section{E. Personal Solicitation Clause}

The ABA Model Code, like many states, ${ }^{416}$ does not permit judicial candidates to "personally solicit or accept campaign contributions." ${ }^{417}$ Instead, a candidate may delegate fundraising responsibilities to a committee created for "manag[ing] and conduct[ing]" the candidate's campaign. ${ }^{418}$ The purpose of assigning the collection of funds to an intermediary is obvious. Personal contact between a judicial candidate and a contributor is thought to create a sense of obligation, or at least the appearance of bias, when that contributor appears as a party before the candidate. ${ }^{419}$ Advocates can cite the mounting body of evidence on correlations between campaign contributions and judicial outcomes ${ }^{420}$ in support of the restriction. In a similar vein, defenders of the ban's constitutionality rest much of their argument on the Supreme Court's decisions upholding limits on contributions to candidates. ${ }^{421}$

Even assuming the continued validity of the Court's campaign finance jurisprudence, however, barriers to personal interactions between judicial candidates and their contributors appear to face a dire future. The Court is likely to find the solicitation clause unnecessary to preserving impartiality much as it found the announce clause ill-

${ }^{413}$ See 416 F.3d at 754-63.

${ }^{414}$ Wildermann, supra note 92 , at 786 .

415 See GASs, supra note 119 , at 1.

416 Id. at 17.

${ }^{417}$ Model Code of Judicial Conduct R. 4.1(A) (8) (2007).

${ }^{418}$ Id. R. 4.1(A) 8, R. 4.4(A).

419 See Republican Party of Minn. v. Kelly, 247 F.3d 854, 883-84 (8th Cir. 2001), rev'd on other grounds, 536 U.S. 765 (2002); Briffault, supra note 94, at 226-27.

${ }^{420}$ See, e.g., Sheila Kaplan \& Zoe Davidson, The Buying of the Bench, The NATION, Jan. 26, 1998, at 11, 15; Liptak \& Roberts, supra note 26, at A1; Texans for Public Justice, Pay to Play: How Big Money Buys Access to the Texas Supreme Court (2001), http:// www.tpj.org/doc/2001/04/reports/paytoplay/paytoplay.pdf [hereinafter Pay to Play].

${ }^{421}$ See, e.g., Republican Party of Minn. v. White, 416 F.3d 738, 785 (8th Cir. 2005) (Gibson, J., dissenting); Briffault, supra note 94, at 225-26. 
designed for that purpose in White. Since that decision, restrictions on candidates' handling of fundraising have unsurprisingly met with uniform hostility in the federal courts. At the same time that it struck down Minnesota's political activity clause, the Eighth Circuit also sustained a challenge to the state's solicitation clause. ${ }^{422}$ In Weaver $v$. Bonner, ${ }^{423}$ the Eleventh Circuit similarly found that Georgia's solicitation clause was not narrowly tailored to serve a compelling interest. ${ }^{424}$ The Court squarely rejected the premise that a candidate's direct involvement with fundraising aggravates the intrinsic risk of bias toward contributors: "Successful candidates will feel beholden to the people who helped them get elected regardless of who did the soliciting of support." ${ }^{425}$ A federal district court recently endorsed the Eleventh Circuit's reasoning in striking down Kansas's solicitation clause. ${ }^{426}$ Whatever the force of this logic as an original matter, these courts appear to have accurately read the thrust of the White Court's brand of strict scrutiny. If anything, the solicitation clause can be considered unusually vulnerable to this review. ${ }^{427}$ The presumed cure for the underinclusiveness identified by the Weaver court-banning solicitation altogether-could not possibly survive constitutional challenge. Moreover, even if it is accepted that some personal solicitations could compromise impartiality, recusal in those cases represents a more narrowly tailored remedy than wholesale prohibition. ${ }^{42}$

422416 F.3d at 763-65. The plaintiffs limited their challenge to the state's ban on candidates' personal solicitation from large groups and on affixing their personal signature on a solicitation message. They did not challenge the requirement that campaign committees refrain from disclosing the identities of campaign contributors or those who declined to contribute when asked. Id. at 764-65.

423309 F.3d 1312 (11th Cir. 2002).

${ }^{424} I d$. at 1322-23. For an argument that the Eighth Circuit's invalidation of both clauses threatens the viability of nonpartisan judicial elections, see Ross G. Currie, Note, The End of Nonpartisan Judicial Elections and the Rise of the Politiciary: The Eighth Circuit Strikes Down Judicial Campaign Regulations in Republican Party of Minnesota v. White, 51 VILL. L. REV. 665 (2006).

Weaver, 309 F.3d at 1323.

${ }^{426}$ Kan. Judicial Watch v. Stout, 440 F. Supp. 2d 1209, 1235-38 (D. Kan. 2006). In a departure from these results, the Supreme Judicial Court of Maine upheld a solicitation clause that barred judges from personally soliciting contributions. In re Dunleavy, 2003 ME 124, 838 A.2d 338. That restriction, however, applied only to sitting judges rather than to all judicial candidates. Id. at 351. This distinction aside, state supreme courts' assessment of canons that they have promulgated are in any event suspect. See supra notes 225-29 and accompanying text.

${ }^{427}$ See Failinger, supra note 21, at 451 (describing requirement that judicial campaigns "erect a screen" between candidates and contributors as "perhaps the most constitutionally suspect" of rules governing financing of these campaigns).

${ }^{428}$ See Stout, 440 F. Supp. 2d 1209, at 1234. 


\section{THE FACE OF UNFETTERED JUdiCIAL CAMPAIGNS AND ALTERNATIVES TO REgULATION}

For champions of judicial exceptionalism, the combination of gutted campaign speech restrictions and an entrenched election system presents a disturbing prospect. Left largely unregulated, judicial campaigns presumably will increasingly resemble their legislative and executive counterparts. In recent years, however, judicial contests have already shed much of their distinctive character. Thus, the difference between the grim scenarios feared by proponents of speech restrictions and the current electoral landscape may not be dramatic.

Indeed, it is commonplace to observe that judicial elections are widely becoming - as Roy Schotland put it—-noisier, nastier and costlier." ${ }^{429}$ Eight years after this comment, a reporter in 2006 similarly described judicial campaigns as becoming "high-stakes political battles-expensive, polarized, and, at times, nasty." ${ }^{430}$ Attack ads, a prominent feature of "normal" campaigns, have been deployed effectively in judicial elections at least since the successful 1978 effort to oust Rose Bird and two of her colleagues from the California Supreme Court. ${ }^{431}$ While some bemoan the impact of such ads on the stature of the judiciary, ${ }^{432}$ this tactic has become a routine part of judicial campaigns. ${ }^{433}$ A small sampling from recent elections captures

429 Roy A. Schotland, Comment, Judicial Independence and Accountability, LAW \& Contemp. Probs., Summer 1998, at 149, 153; see Champagne, supra note 251, at 669 (describing transformation of "low-key, low-budget" judicial campaigns to "hotly contested, expensive races that often cannot be distinguished from contests for offices in the political branches").

${ }^{430}$ Scott Michels, Judicial Elections Turn Expensive, Polarized, and Nasty, U.S. NEWs \& WORLD REPORT, June 6, 2006.

${ }^{431}$ See Robert S. Thompson, Judicial Retention Elections and Judicial Method: A Retrospective on the California Retention Election of 1986, 61 S. CAL. L. REV. 2007, 2038 (1988) (describing campaign mounted by opponents as "a blatant appeal to emotion and desire for revenge"). A similar approach helped defeat Justice Penny White of the Tennessee Supreme Court in her 1977 retention election. See Stephen B. Bright, Political Attacks on the Judiciary: Can Justice Be Done Amid Efforts to Intimidate and Remove Judges from Office for Unpopular Decisions?, 72 N.Y.U. L. REv. 308, 313-15 (1997).

${ }^{432}$ See, e.g., Berness, supra note 16, at 1031 (asserting that the use of negative ads threatens to "erode the public's trust in the American justice system and its judges ").

${ }^{433}$ See Champagne, supra note 251, at 673 (concluding that studies of judicial elections in four states in 2000 confirmed theory that candidates' ads "highlight easily absorbed negative messages about the opponent") (quoting STEPHEN ANSOLABEHERE et Al., The Media Game: American Politics in the Television Age 100 (1993)); see also M.J. Ellington, Attack of the Negative Ads, The Decatur Daily (Ala.), Oct. 22, 2006 (quoting Alabama political scientist that State's judicial races had become negative about a decade earlier and that "judicial candidates are sliding down the slippery slope of political muck"). 
the flavor of many of these attacks. "He sexually molested multiple West Virginia children . . . Liberal Judge Warren McGraw cast the deciding vote to set this reprehensible criminal free." "Carol Hunstein ... voted to throw out evidence that convicted a cocaine trafficker ... [she] even ignored extensive case law and overruled a jury to free a savage rapist." 435 "First [Judge Nancy Saitta] took thousands in contributions from two convicted topless club owners. Then she slashed bail for gang bangers who brutalized an MGM employee." ${ }^{436}$

As for "costlier," expenditures on judicial races have also begun to catch up with their legislative and executive counterparts. As has been amply documented, money is poured into judicial campaigns at levels that would have been considered staggering only a short time ago. In 2000, candidates for state supreme courts as a whole exceeded previous records for fundraising by $61 \% .{ }^{437}$ By 2004, the average amount of funds raised by winning candidates leapt to forty-five percent over the average for 2002. ${ }^{438}$ Early figures compiled for the 2006 campaign season indicate that expenditures have continued to escalate. ${ }^{439}$ While the latest scale of contributions and spending may fuel cynicism about judges' aloofness from political considerations, widespread suspicion about the influence of money has existed for years. ${ }^{440}$ In the minds of much of the public, then, judicial races have been steadily evolving into politics by other means. ${ }^{44}$

${ }^{434}$ Adam Liptak, Judicial Races in Several States Become Partisan Battlegrounds, N.Y. Times, Oct. 24, 2004, at A1.

${ }^{435}$ Press Release, Brennan Ctr. for Justice, Once Courtly, Campaigns for America's High Courts Now Dominated By Television Attack Ads (Nov. 2, 2006), http:/ /www.brennancenter.org/press_detail.asp?key=100\&subkey= 38281 .

${ }^{436}$ Id.

437 See Roy A. Schotland, Financing, supra note 33, at 850 \& n.6.

438 Deborah Goldberg et al., The New Politics of Judicial Elections 2004 (2005), available at http:/ /www.justiceatstake.org/files/NewPoliticsReport2004.pdf.

439 See, e.g., Brennan Ctr. for Justice, Buying Time 2006: Sponsor, Airing, and Cost, available at http://www.brennancenter.org/dynamic/subpages/download_file_4714 0.pdf; Press Release, Brennan Ctr. for Justice, Two Years After Record-Setting Supreme Court Campaign, Illinois Appellate Court Campaign Record Smashed (Oct. 24, 2006), available at http://www.brennancenter.org/press_detail.asp?key=100 \&subkey=47155.

${ }^{440}$ See Stuart Taylor, Gagging Judicial Candidates Won't Save State Courts, NAT'L L.J., Mar. 25, 2002; Kara Baker, Comment, Is Justice for Sale in Ohio? An Examination of Ohio Judicial Elections and Suggestions for Reform Focusing on the 2000 Race for the Supreme Court, 35 Akron L. Rev. 159, 160-66 (2001); Kaplan \& Davidson, supra note 420, at 11, 15; Pay to Play, supra note 420.

${ }^{441}$ See, e.g., Glaberson, supra note 357, at A1; Baran, supra note 34, at 13 (asserting that in states with partisan elections, "political parties see judicial elections as part of an overall political agenda"). 
Against this backdrop, the tumbling of remaining speech restrictions may only aggravate somewhat a substantially politicized process. As for dangers specifically posed by unrestrained speech, these were largely unleashed by White's invalidation of the announce clause. Even before the likely fall of the commit clause and pledges or promises clause, judicial candidates can effectively signal their intent concerning the disposition of legal issues. More than one commentator noted the ease with which candidates can "telegraph" the types of rulings the electorate can expect from them. ${ }^{442}$ Indeed, the climate of laxity engendered by White may have induced some candidates to go further and assume the invalidity of restraints on more explicit declarations of their intentions. ${ }^{43}$

Perhaps resigned to the futility of eliminating judicial elections or enforcing speech codes, proponents of reform have advanced other means to curb the excesses of judicial campaigning and promote the election of worthy judges. These proposals fall roughly into three categories: voluntarist, informational, and structural. Perhaps the most straightforward voluntary approach is conversion of mandatory restraints on speech to guidelines that candidates are urged to follow. ${ }^{444}$ Compliance with these norms could be monitored by nongovernmental groups created for this purpose. ${ }^{445}$ Of course to have any meaningful impact on campaigning, such panels would have to

${ }^{442}$ See Bogard, supra note 91, at 17; Recent Changes, supra note 125, at 836 (remarks of Bill Weisenberg).

${ }^{443}$ In one instance, a candidate volunteered his belief that homosexuals should not be permitted to adopt children. Matthew Eisley, Bench Hopefuls Bank on Personal Beliefs, The News \& ObServer (Raleigh, N.C.), Oct. 31, 2004, at 30, available at http:// www.newsobserver.com/954/story/271102.html. Another candidate, after harshly criticizing decisions invalidating Ohio's scheme for school funding, told an assembly of teachers from the Ohio Education Association that his election would send a "simple and direct message to the out-of-control Ohio General Assembly: When you come to Columbus in January, bring your toothbrushes, because you will be staying until you comply with the laws of the State of Ohio." Andrew Goldstein, Money Talks, LEGAL AFFAIRS, Jan.-Feb. 2005, at 29 (internal citation omitted). One candidate went so far as to declare that "I pledge to hold the line on new taxes." Press Release, Brennan Ctr. for Justice, TV Advertising in Texas Judicial Races Gets Off to an Early Start: More than $\$ 270,000$ Spent in Primary Elections for Lower Courts, Mar. 9, 2006, http:/ /www.commondreams.org/news2006/0309-12.htm.

${ }^{444}$ See GASS, supra note 119, at 24-25 (advocating "aspirational" standards of conduct); Ogunro, supra note 96, at 23 (describing voluntary compliance with speech guideline as "[o]ne of the most noncontentious viable solutions" to the problem of unregulated campaign expression).

${ }^{445}$ See Ferris K. Nesheiwat, Judicial Restraint: Resolving the Constitutional Tension Between First Amendment Protection of Political Speech and the Compelling Interest in Preserving Judicial Integrity During Judicial Elections, 24 QUINNIPIAC L. REV. 757, 760 (2006); CALL TO ACTION, supra note 25, at 30-31. 
publicize candidates' adherence to or departure from the recommended standards; ${ }^{446}$ they would thus perform an important informational function. Nor would the communications undertaken by these or similarly proposed groups be confined to reporting candidates' scorecards. As envisioned by numerous commentators, a broader campaign of public education would offer voters profiles of candidates and explanations of the larger judicial role. ${ }^{447}$ Candidates might also benefit from campaign conduct committees, which would "serve as a resource for judges and judicial candidates, [and] assist in educating judges and judicial candidates about ethical campaign conduct." "48 High on some agendas, too, are disclosure laws that would alert the public to the identities of campaign contributors and the extent of their generosity. ${ }^{49}$ The prospects for widespread adoption of such proposals, much less their efficacy, remain uncertain. They would, however, carry out Justice Kennedy's charge in White to the legal profession and other interested parties to "reach voters who are uninterested or uninformed or blinded by partisanship, and ... [to] urge upon the voters a higher and better understanding of the judicial function and a stronger commitment to preserving its finest traditions." 450

As to revision of the formal rules governing judicial elections, proposals have focused on mechanisms to enhance the independence of successful candidates once in office. An idea with widespread support-endorsed even by a vigorous opponent of speech restrictions $^{451}$-is to lengthen judicial terms in order to diminish pressure from popular opinion. ${ }^{452}$ One observer called it " $[\mathrm{t}]$ he most important single step" to address the challenges posed by judicial elections. ${ }^{453}$ Public financing of judicial elections, notably undertaken by North Carolina in the wake of White, ${ }^{454}$ has been advanced by many as

${ }^{446}$ See Nesheiwat, supra note 445 , at 760, 791.

${ }^{447}$ See, e.g., Ifill, supra note 236, at 98; Wildermann, supra note 92, at 795.

448 Joe Gyan, 'Restraint' Urged After Rules Relaxed in Judicial Elections, THE ADVOCATE (Baton Rouge, La.), July 20, 2002, at 2B (quoting recommendation of National Symposium on Judicial Campaign Conduct and the First Amendment).

449 See, e.g., Goldberg et al., supra note 438, at 36.

${ }^{450}$ Republican Party of Minn. v. White, 536 U.S. 765, 795 (2002) (Kennedy, J., concurring)

451 See Snyder, supra note 48, at 237-38, 258.

${ }^{452}$ See, e.g., Symposium, Judicial Elections and Campaign Finance Reform, 33 U. TOL.

L. REV. 335, 340-41 (2002); CALL TO ACTION, supra note 25, at 16-17.

453 Schotland, Should Judges, supra note 15, at 11.

454 Goldberg et al., supra note 438, at 21. 
a means of curbing the influence of campaign contributors. ${ }^{455}$ In addition, proponents of reducing the influence of political parties naturally favor nonpartisan elections; ${ }^{456}$ White, however, has called their constitutionality into question. ${ }^{457}$

To those who fear the politicization of judicial selection, of course, all of these proposals remain second-best solutions. Ideally, they would rather replace elections altogether with an appointment system, or at least a variation of the Missouri plan combining merit selection and retention elections. ${ }^{458}$ Some observers, however, contend that shifting to appointments will fail to purge judicial selection of politics; rather, the choice of judges is "an inherently political process." ${ }^{459}$ Indeed, a commentator recently argued that the phenomenon of "prejudging judges" is more pronounced in the appointment process than in elections. ${ }^{460}$ In any event, the debate over the relative merits of the two methods promises to remain academic, as citizens persist in refusing to yield the franchise. And whatever the politics of judicial elections, they are unlikely to be hindered by restraints on campaign speech in the years to come.

\section{CONCLUSION}

It is easy to lament the corrosive effects of selecting judges by the same political process we use for legislators and executive branch officials. The regrettable tactics of modern campaigning-visceral appeals, simplistic reduction of complex issues, shrill ad hominem attacks, the lavish expenditure of funds by interest groups-are even more disturbing when employed to determine the members of a supposedly impartial and principled judiciary. Mostly unsuccessful in efforts to supplant elections with appointments, the bar has understandably turned to limitations on candidates' speech to temper the excesses of judicial campaigning. The Court's decision in White, however, sent an unmistakable signal that the First Amendment

${ }^{455}$ See, e.g., Carter, Boosting, supra note 92 , at 34 ; Goldberg et al., supra note 438, at 37; Ifill, supra note 236, at 93-95.

456 See, e.g., Call to ACTiOn, supra note 25, at 14-15.

${ }^{457}$ See Schotland, Should Judges, supra note 15, at 8-9.

458 See supra notes 28-31 and accompanying text.

${ }^{459}$ Camille M. Tribble, Awakening a Slumbering Giant: Georgia's Judicial Selection System After White and Weaver, 56 Mercer L. Rev. 1035, 1035 (2005); see Jonathan L. Entin, Judicial Selection and Political Culture, 30 CAP. U. L. REv. 523, 540-56 (2002) (analyzing influence of political considerations in federal judicial appointments).

${ }_{460}$ See Jonathan Remy Nash, Prejudging Judges, 106 CoLum. L. ReV. 2168, 2180-99 (2006). 
largely forecloses this means of curbing political elements of an intrinsically political process. The Court's confinement of that holding to Minnesota's announce clause reflects no more than the absence of additional restrictions to consider on that occasion. Justice Ginsburg's forlorn protest that " $[\mathrm{j}]$ udges are not politicians, and the First Amendment does not require that they be treated as politicians simply because they are chosen by popular vote" ${ }^{\$ 61}$ appears destined to fall on deaf ears when other provisions of campaign speech codes arrive before the Court. Thus, the latest version of the ABA Model Code, as well as comparable state canons, likely amount to rearguard resistance to the inexorable implications of White. Just as the bar was repeatedly rebuffed in its attempts to stem lawyer advertising, ${ }^{462}$ so it now faces the prospect of an equally dismal track record in seeking to contain campaign expression. Justice Kennedy's faith that "democracy and free speech are their own correctives" ${ }^{463}$ may be open to doubt, but they will be all that remains when censorship of judicial candidates is eliminated.

${ }^{461}$ Republican Party of Minn. v. White, 536 U.S. 765, 821 (2002) (Ginsburg, J., dissenting).

${ }^{462}$ See, e.g., Peel v. Att'y Registration \& Disciplinary Comm'n of Illinois, 496 U.S. 91, 110-11 (1990); Shapero v. Ky. Bar Ass'n, 486 U.S. 466, 479 (1988); Zauderer v. Office of Disciplinary Counsel, 471 U.S. 626, 647-49 (1985); Bates v. State Bar of Ariz., 433 U.S. 350, 366-79 (1977).

White, 536 U.S. at 795 (Kennedy, J., concurring). 